University of Louisville

ThinkIR: The University of Louisville's Institutional Repository

Electronic Theses and Dissertations

1941

\title{
Milton's thought on divorce.
}

Annie Murray Ferry 1906-1973

University of Louisville

Follow this and additional works at: https://ir.library.louisville.edu/etd

Part of the Family, Life Course, and Society Commons

\section{Recommended Citation}

Ferry, Annie Murray 1906-1973, "Milton's thought on divorce." (1941). Electronic Theses and Dissertations. Paper 1788.

https://doi.org/10.18297/etd/1788

This Master's Thesis is brought to you for free and open access by ThinkIR: The University of Louisville's Institutional Repository. It has been accepted for inclusion in Electronic Theses and Dissertations by an authorized administrator of ThinkIR: The University of Louisville's Institutional Repository. This title appears here courtesy of the author, who has retained all other copyrights. For more information, please contact thinkir@louisville.edu. 
UIIVERSITY OF LOUISVILLE

MIITON'S THOUGHT ON DIVORCE

\author{
A Diseortation \\ Submitted to the Fraculty \\ Of the Graduate School of the Univeraity of Loniavill. \\ In partial sulfiliment of the \\ Requirements for the Degree \\ of Master of irts
}

Department of Bnglish

By

Anie Marray Ferry

Year

1941 
TAME OF STUDENT;

TITLE OF THESIS: MILTON'S THOUGHT ON DIVORCE APPROVED BY A READING COMMITTER COMPOSED OF THF FOLLOWING MEMBERS:

NAME OF DIRBCTOR:

DATE: Zney 18,1941 
MIITON'S THOUGHT ON DIVORCE 
TABIE OF CONTENTS

PAGE

PREFACE

PART ONE

CHAPTER

I

MODERN ATTITUDES TORARD DIVORCE . -

Roman Catholic attitudo ..... 2

Fastern Catholic attitude.... 6

Protestant attitude....... 8

Secular attitudes ........ 11

Attitudes in the United States . . 14

II

DIVORCE DISCUSSION IN ENGLAND 1534-1643

17

In the Anglican Church ..... 19

Among the Puritans and Independents 22

Immediate background for Milton . . 27

III UIITON'S PARTICIPATION IN DIVORCE DISCUSSION ............

29

Milton's interest in divorce: intellectual or personal? . . . 29

Milton's background ....... 37

Attitude toward women ...... 37

Marriage .......... 40

summary ............ . 41

Reopening of dirorce discussion . . 42

other divorce contributions .... 44

Popular and literary references . . 50 
PART TWO

CHAPTER

IV

SUMALAR OF DIVORCE TRACTS . . . . . 53

Dootrine and Discipline of Divoree. - 54

Judgment of Martin Bucer. . . . . 70

Tetrechordon. ........... 77

Colasterion ...... . . . . . 88

Christian Doctrine. . . . . . . 90

Summary . . . . . . . . . . . 91

$\checkmark$ ANALYSTS OF MITTON'S MFTHOD OF

REASONIITG . . . . . . . . . . . 98

Direct use of scripture ....... 94

The apperl to Reason. . . . . . 95

The sanction of Nature....... 105

The nature of man.......... 107

VI CONCLUSIONS . . . . . . . . . . 113

BIBLIOGRAPHY .. . . . . . . . . . . . . . 177 


\section{PREPACH}

The purpose of this paper is to examine John wliton's contribution to the discussion of the problem of divorce. Milton's divorce tracts have long been the subject of much discussion by scholers, but no extended effort has been made to stady them either historically or in the light of the modern attitudes towards the divorce problem.

As necessary background for the summary of Milton's ideas on dirorce and the analysis of his method of reasoning in the second part, the first part of this thesis will contain: (1) a review of the major attitudes towards divorce in the present day, (2) a detailed background of English thought on divorce up to Milton, and (3) a discussion of Milton's own beckground for his writings on divorce.

The analysis of Milton's thought against this background shows its curious anticipation of modern secular thought on divorce. 
CHAPTER I

MODERN ATIITUDES TOWARD DIVORCE

The first section of this paper is concerned with sketching a background for an ansigsis of Milton's divorce tracts. It consists of three chapters: Modern Attitudes toward Diroroe, Dirorce Discussion in England 1534-1643, and Milton's Participation in Dirorce Discussion.

The purpose of the first chapter is to give a general idea of the attitudes toward divorce that exist today in Western culture, and a summary of their historical development. Necessarily the sources used for this chapter have been secondery. To prevent presenting a one sided pioture, I consulted rarious encyclopaedias: the Catholic Encyclopedia ${ }^{1}$ for the Catholic viewpoint, Hestings' Encrelopaedia of Religion and Ethios ${ }^{2}$ for the liberal Protestant, the Encyclopaedia of the Social Solences $^{3}$ for the secular. For specialized aspects of the problem these sources were supplemented with current articles from the Social Science Abstracte ${ }^{4}$ and the

1. The Catholic Fncrolopedie the York: the lincyclopedie Pre8s, 1909.

2. Fncrciopaodia of Religion and Ethies (James Hastings, ditor; New York: Chas. Sertbner's and Sons, 1925).

3. Encyclopadia of the Soclal Sclences (Hew York: Kacmilian Co., 1937).

4. Social Science Abstracts. 
United States Census Report (1930). 1

an overview of Westerm thought on divorce shows that attitudes toward marriage and divorce have been developed through three phases: Cathollc, Protestant, and secular. These three points of view represent sucoessive developments historieslly as well as forces still operative at the present time.

Therefore this chapter has been divided into three seotions. At opposite poles are the catholic and modern secular conceptions. Ocoupying the middle ground are the beliefs held by the Protestant churches. First, then, w11l be presented the fundamental Catholic doctrine; seconaly, the Protestant which is the heir of Milton'a Fnglend; and thirdly, the secular which, strangely onough, by a different procese of reasoning, has the same inal attitude toward divorce as Milton, that of divorce for incompatibility by mutual consent.

\section{THE ROMAN CATHOLIC ATTITUDE}

The Roman Catholio attitude toward dirorce is determined by its conception of marriage a a sacrament. There is no dirorce possible in the accepted sense of the word where a marriage can be terminated leaving the 
contracting partios free to remarry. However, since it is within the jurisdiction of the church, as the custodian of the sacraments, to interpret and apply the difine law of marriage, modifioations of the marriage law exist.

Sacraments, in the Catholic church, are the "effectual signg" of grace. That is, they are the outward signs of an infard grace, instituted by christ for sanctification. In a marriage ceremong the contracting parties are the ministers as well as the recipients of the sacrament. Because of this, the church recognizes the fact that a marriage can be invalid or illicit depending on the qualification of the contracting parties. 1

The first modification 18 therefore in favor of the faith. A non-Christian marriage can be dissolved by absolute divorce. This is often callod the pauline privilege, the Magna charta in faror of the Christian falth, because of the words of St. Paul, ". . but if the unbeliever depart, let him depart." 2

The second modification of the marriage law admits that a Chriatian marriage before consummation

\footnotetext{
1. Kennedy, De Je' "Sacramenta," the catholle Frayclopodia, XIII, 302 .

2. Smith, W. G., "Dirorce," The Cathollc Encyclopedia, $\nabla, 60$.
} 
can be dissolved by solemn profession in a religions order or by an act of papel authority. In either case remarriage is permitted. The acts of papal authority are based on the theory of an invalid sacrament. These impediments to a licit marriage contract are in four flelds: (I) physical, involving impuberty or impotency of one of the parties; (2) form, that 18, clandestinfty; (3) defect of consent: Insanity, ignorance, or coercion; and (4) relationship or consanguinity. 1

No divorce permitting remarriage is the separation a mensa ot thoro accepted by the church for the hardness of men's hearts. It is merely a recognition of the fact that under certain conditions marriage, instituted for the welfare of the family, defeats its own ends. Under It separation from bed and board is allowed for various causes, especially in the case of adultery or lapse into infidelity on the part of husband or wife. The grounds can be classffled under four headinge: (1) choice of - vangelical perfection, (2) adultery, (3) heresy or defection of the faith, and (4) danger to body or soul. 2 Thus it can be seen that the Catholic divines sanotioned inviolate marriage, indissoluble and monogemous, with onls slight modifications and accommodations 
to the contrary, to promote in the highest degree the welfare of the family. ${ }^{I}$ This can be considered the basic Christian idea of marriage, doveloping with the Chrietian religion. From this concept the various Protestant attitudes developed with the Reformetion. The first dogmatic decieion on the question of the indissolubility of marriage was made by the councll of Irent (Session 24 - Canon 5): "If anyone shall say that the bond of matrimony can be dissolved for the cause of heresy, or of infury due to cohabitation, or of milful desertion; let him be anathema.n2 Prerious to that time "the synods of the centuries and the deorees of the popes have constantly declared that dirorce which annulled the marriage and permitted remarriage was nover allowed." But ". . the practice of the faithful was not always indeed in accord with the doctrine of the churoh." 3 Until the firm stand of the Counoil of Irent, the practice of divorce had fluctuated according to the general laxness of the morals of the Christian church,

1. LohnkwhI, Lug., "Marriage," The Catholic snoyclopedia, IX, 698. "The fact that the union is indissolubie and monogemous promotes in the highest degree the welfare of children and parents, and stimulates In the whole community the practice of those qualities of self restraint and altruism which are ossential to social well being, physical, mental, and moral."

2. Smith, op. cit., p. 68 .

3. Loc. o1t. 
especially around the 10th century. Sinoe the counoil of Prent the doctrine of the Romen Catholic church has remained the same.1

The Roman Catholic conception of marriage with It accompanying conception of divorce today applies to good cathollcs everywhere in whatever country they may Iive rogardless of the civil laws of that country. Papal authority todey prevailo in Italy, Spain, the Irish Froe state, and Austria (for Catholics only).2 In countries where the Catholic population is heary, this conception of marriage and dirorce has affected or modified the legal or state attitudes toward the problem.

\section{THE BASTERN CATHOLIC ATTITUDE}

The Eastern Cathollc Church, which consists of fourtoen eelf-goterning churches, considers itself to be the canonical and genuine hoir to the ancient church. It accopts the firat seren councils of the Roman Catho11c Church, but the Wostern Church seperated itself under the pope by introducing innovatione regarding faith. Hence the Eastern doctrine concerning divoroe is not that of the Roman Catholic. Marriage is con-

1. HIa., p. 59 .

2. Hankins, Frank, "Dirorce," Bnoyclopeodia of the Social Sciences, V, 179. 
aldered one of the seven sacraments, but the separation of the charches occurred before the strict doctrine of the Council of Trent, and since the Eagtern church has never been as strong as the Festern, it had to defer more to eivil laws and lay opinion. ' one might say that its attitude was more nearly that of the protestant church in Protestant oountries.

Absolute dirorce is allowed in the Eastern church but judiciel separation 18 not. $\triangle$ man or a woman may bo divorced only once. There are many grounds rarying in the different countries, but some grounds are common to 211: (1) adultery, (2) attack on life, (3) serious maltreatment, and (4) sentence to penal servitude. It can thus be seen that the causes which to the Roman Catholio were merely reasons for separation a mensa et thoro, permit remarriage in the Eastern churches. Additional grounds in rarious countries range from physical disability anch as insantty or opilopsy, to social tabus such as are incorporated in the Justinian code in effect in Greoce. There a husband may dirorce his wife if she attende dinners without his coneent. 2

1. Archishop Porphyrios, "The Eastern Charch," Bnorclopaedia of Religion and Ethics, V, 134.

2. Ground for dirorce in Serbia, Bulgaria, and Rumania: absolute dirorce (1) adultery, (2) attack on life, (3) seriou maltreatment, and (4) sentence to penal servitude. Additional grounds in Bulgaria: wilful 
The provenience of the Eastern church today is small becanse of the withdrawal of Russia with the revolution. In Europe today it applies to Serbia, Bulgaria, Rumania and Greece. It is, howerer, of interest to us beoanse of the quantities of immigrante from those lands who have brought with them their culture to America.

III. THE PROTESTANT ATMITUDE

The 16th century Reformation brought a different attitude to those who accepted the Protestant faith. As the Roman Catholic church tightened its grip and its rules became more strict, the Protestant reformers gave the people a now idea of man's responglbility. Historically the Protestant church is rooted in the medieval

\footnotetext{
desertion, abence without news or non support for four years, Impotency, insenity, opilepsy, 1diocy, syphilis, unnatural sex congress, restraint of religious liberty, drunkenness, persistent 1mmorality, and unsustained charge of adultery. Additional grounds in Serbia: absence without news for four years and apostasy. Additional grounds in Hungary: bigamy, unnatural crime, malicious desertion, persistent imorality, and inducing one's own ohild to immoral or criminal act. In Greoce the Justinian code is in effect. Grounds for the husband are: adultery, spending the night out, going to the theater without consent, and bathing in company of men without his permission. There the wife can get a divorce if her huoband: conspires against the government, attempts her life, plots against it or shields others, attempts to induce her to adultery, falsely accuses her of adultery, commits adultery in the home, persists in adultery in the ame town, and is impotent when married and continues so for three joars. Hankins, op. c1t., p. 179.
} 
Roman Cathol10 and Eastern Catholic churches, and many of 1ts 1deas remain the seme. The transcondental character of marriage was still recognized, but the change was that marriage was no longer considered one of the sacraments. It becama, in the ejes of the protestant church, oivil contract which could be dissolvod, and the accommodations for divorce became broader. To be sare the chief ground for divorce remained that sanotioned in the Bible, adultery, but romarriage of the innocont party was accepted by the church. Protestant groups have been more divided than Catholic on the subject of divorce. Today we find in Protestant countries three general dirisions of thought. First and narrowest is the attitade of the churches, most of which sanction divorce for one cause only, adultery. In rare oases malicious desertion is accopted. Secondy, there is the widened $\nabla 10 \mathrm{w}$ of the problem as - oridenced by the legel grounds of the different countries. These range from adultery, to excessive cruelty, to mutual consent. Finally there is the moral vier of the poople which cannot be measured accurately, but which must be estimated only. Although the actual grounds may be slight, with connivance the law can be circumvented. Geographically there are three general groups into whioh protestant ohurches can be dirided: Ingland, 
continental Furope, and the Scandinavian countries. These groups represent, according to legal ground and social accoptance, a variation from the strictest to the most lonfent forms of divorce in Protestant countries. In England the attitude toward dirorce is nearest that of the Roman Catholio. The Church of England, although separated in gorernment, was never separated in thought from the Catholio so a strict form of marriage 18 observed there. Until 1857 an Act of parliament was necessary to obtain a dirorce. That is not true today but the legal grounde have been limited. The Church has frowned upon remarriage, and the midale and upper clas8es have not accepted the dirorceo socially. Therefore the divoree rate in England is the lowest for any Protestant oountry, about .I per 1000 of population. ${ }^{1}$

The Protertants of continental Buropo hare made more modifications than the English. In Austria, - Germany, and Switrerland the grounds range from adultery to gross abuse, dishonorable conduct, and invincible aversion. In France conviction of a crime involving moral degradation can be a cause of divorce. Holland

\footnotetext{
1. In ingland divoreos are not olfoctive for six monthe after the decree. Grounds are: adultery, desertion for two years, rape or unnatural offenses. In Scotland: adultery and wileul desertion. In Canada: adultery, impotency, consanguinity, oruelty and desertion. Henkins, op. olt., p. 180.
} 
and Belgium grant a limstod number of divorces for mutual and unwavering consent after judicial seperation for four years. In these countries it can be seon that the legal grounds have been widened and nsed because the churches have not had so strong an effect on the lay opinion. 1

IV. SECULAR ATIITUDES

The modern rationalistic basis of reasoning about oocial probleme has grown steadily since the Industrial Revolution. A former agrarion society with it peoplo bound by traditional religious viows and oustoms has boen changed to an Industrializod urban socloty. With the uprooting of familles in their move to the oity oame

1. Common ground in Germany, lustria, switzerland: adultery, bigamy, unnatural crime, attempt on life, Tilful desertion, gross abuse. Additional ground In Germany: insanity, violetion of marital duties, dishonorable or 1mmoral conduct. Additional grounds in Austria: Immorality, infectious disease, sentence to penal servitude, long absence without news, invincible aversion. Aditional grounds in Switzerland: insanity and invincible aversion. In Belgium the grounds are: mutual and unwerering consent with judicial approval, adultery of wife, adultery of husband if the mistress hes been kept in the house, excoseive violence or cruelty, greve indignities, and conviction of an infamous offense. In France the grounds are: adultery, personal violence, cruelty, grave indignities, conviction of a crime involving 1mprisonment and moral degradation, and three years judicial separation. In Holland the grounds are: adultery, malicious desertion, four years 1 mprisonment, gross 111 treatment, mutual consent after four jears judiciel separation. Hankins, op. cit.., p. 180. 
a foeling of impermanence which carried over into their moral and religious lifo. A materialistic viempoint on Iife dereloped which, with the growth of scientific mothods of thought, cansed a new approach to social problems. Faith and the Bible were no longer the basis of reason; soientific analyses were substituted to solve man'o social problem. With the good of man and his happinese at etake, a hodonistic attitude 788 prodominant. Man's present happiness and good were more to be desired than pleasing God in traditional forms.

This non-religious vierpoint, a secular, rationalistic, material outlook, has been increasingly in evidence in the modern attitude toward marriage and divorce, particularly in modern Russia. It can be traced in the riaing divorce rates of all countries. ${ }^{1}$

In Rusgia with no church background, no christian interpretation of government, marriage hes become a simple civil ceremony, and divorce an equally simple problem. Mutuel consent, or even an individual request

1. In Japan an interesting situation exists as a result of modern social problems. There industrializetion, urbanization, and the rise of fominism have contributed to a constantly lowering divorco rate as compared with one that is riging in all wostern contries, Modern life is making obsolete the child marriage which contributed to the formerly high rate. Iwasak1, Yasu, "Divorce in Japan," Americen Journal of Soolology, SXXVI (1930), 435-446. Social Science Abstrect8, III (1931), 448. 
provided notice is put in the paper, is sufficient to dirorce couple. Marriage oan still be conaidered monogamous there because it is 11 legal to register for a marriage if living in a married state with another. The diroroe rate is very high, 14.3 per 1000 ag compared With 1.6 per 1000 in the United States. ${ }^{1}$

With the exception of Russia the greatest divergence from Catholic thought is found in the Scandinavian oountries. From 1918-1922 the countries of Norway, Swoden, and Denmark adopted a common divorce code allowing divorce on mutual consent. Today $75 \%$ of their diroroes are granted on the charge of incompatibility. The decree is granted after a year's probation period in which the pastor or some responsible person designated by the court makes an attempt at reconciliation. In these countries the lay of secular opintion has done much to broaden the legal grounds, and the orthodox church attitude is in ovidence only in the comparatively small number of dirorces granted, about one fourth that of the United Stater.2

1. Pasche-0serki, N., Mkerr18ge and Dirorce in Soviet Rusaia," Neue Generation, VIII-IX (1929), 225-231. Stolal solence Lbstracts. II (1930), 720 .

2. Complete grounds in tho scandinavia countrie a are: malual consent after one jear's separation, living apart three years, wilful desertion of two jeare, absence with whereabouts unknown three years, neglect of domestic duties, bigamy, adultery, exposure of pouse to venereal infection, plotting against lifo, severe physical mistreatment, sentence to hard labor for three yeare, arunkenness, incurable insanity for three years. Hankins, op. cit., p. 180. 
V. ATTITUDES IN THE UNITED STATES

The attitude of the United States towarda the divorce problem has parposely not been stated up to this point because in our country we find a cross section of all the attitudes previously mentioned. The catholics observe the papal canon law, and devout protestants admit only the nerrow ground of the church, desertion and adultery, no matter wat legal grounds are offered. The 1 aws of the states also reflect every attitude from no divorce on ang grounds in South Carolina, whtch has a Catholic background; divorce for adultery only in Hew York; adultery, cruelty, or desertion in New Jersey; and about oight grounds following a fundamental protostant pattern in each of the other atates.1 The attitude of the courte to the law also veries from a generally strict observance in the East which becomes more freo and broad as one fournoys west, making possible the easy Nevada dirorce.2 The secular and lay opinion in the United States ha been reflected more in influenolng the çourts to obtain airorce decrees easily, rather than

1. Hankins, op. c1t., p. 183 .

2. Cahon, Alfrod, Statisticel Analysis of Amerioan Divoroe (New York: Columbia University Pross, I932), p. 34. 
in modifying existing laws.'

That this secular attitude is growing can be seen in the increasing number of dirorces granted on grounds not approved by any church. Cruelty, desertion, and neglect to provide as grounds for dirorce account for two thirds of those granted in the United states. That they are usually used as a screon for divorce by mutual consent is recognized by leading legal authoritiee. A partial explanation of the lenienoy of the courte is found in Barnott's Dirorce and the American Dirorce Hovel:

The blame for marriage which end in the divorce court is placed more and more on forces and condltion external to the indiridual. Poor preparation for marriage, bed chlldhood environment, selfish and carelees parents bear the onus for the divorces of their children. Some even in more recent years have insisted that divorce, oren if it be a nocessary evil, may work good in the lives of those confused in marriage...

1. The canses of diflerences in frequency of divorces in various states are complex. The fact that the states with the highest rates are with the exception of Texas and Oklahome in the Pacific and mountain divisions is explained by the fact that the population is of netire stock and Protestant religion and that its original individualism in political and

- social tradition has been accentuated by frontier experience. Low rates and slow increase are associated with New England and the midale Atlantic states with traditional conservatism and large forelgn born Catholic populations, and in the south stlantic states With conservative Protestantism, rural isolation, and the retardation of economic derelopment." Hankins, op. cit., p. 183. 
There is a ahift from the definite condemation of dirorce as a moral and social evil... to a more recent viow that divorce is a fact for whioh there is an explanation and a canse.I

1. Barnett J. H., Divorce and the Amerloan Drrorea Hovel (Philadelphia: Univeraity of Ponneylvania PrOB8, 1939), p. 137 . 


\section{CEAPTER II}

\section{DIVORCE DISCUSSION IN ENGLAIID 1534-1643}

Eerly in the 17th century three general schoole of thought were represented in England. These were the Catholic, the Anglican or State church, and the Protestant. The three epproached the common problem of dirorce from different angles. The Catholic hes already been discussed. In thet church loose attitudes and practices were brought under control by the firm policy of the Counc1l of Trent (1545). The Anglican churoh continued the Catholic policy previous to the council of Trent. Since the church was controlled by the state, the problem betore the king. Parliament, and high church officials consisted in forming adequate and correct legislation, and in correct administration. The protestant or Dissenters' attitude was one of constant agitation and controversy in which all actions of the Anglicen church contrary to their beliefs were quostioned. Since the power of the catholio church was broken in England, no further discussion of its continental activities will be attempted here. The problem of this chapter will bo to sketch the Anglican logislation and administration concerning divorce; and controversies 
raised by the Puritans and Independents, ${ }^{1}$ culminating in their program drawn up in the assembly of 1643 and in Milton's divorce tracts.

A discussion of the status of marriage and divorce in Fingland previous to and contemporary with Milton is included in Powell's English Domestic Relations 1487-1653. 2 This book, according to its subtitle, is "a study of matrimong and family life in theory and practice as revealed by the literature, law, and history of the period." In it has boen gathered all the arallable material. Ingliah Domestio Relations, however, covers much more of English life than is necessary to this study. The chapters on Controversies Regarding Marriage, Contemporary Attitudes toward Women, and Wider Ranges of Iiterature, form an excellent background for the times, but do not contribute directly to the problem of divorce as does the chapter, The Attempted Reform of Dirorce. The material presented there is here roorganized and summarized from the point of view of my

1. The terms Paritan and Indepondent will be used almost synonymousiy here. Although the Puritan were originally interested chietig in reform within the church, and the Independents prone to follow the more liberal practices of the Germans, their common cause of objoction to the Iaws and administration of the Anglican Church me them one in a discussion of the divorce situation.

2. Powell, Chilton I., Engl 1sh Domestic Relations 14871653 (New York: Columbia University Pres8, 192r). 
Investigetion.

I. IN THE ANGLICAN CHURCH

First consideration must be given to the situation within the Anglican churoh. There reform was attempted, but the legislative and legal status of marriage and divorce remained the same, and upon the mass of 1ts membership the Puritan 1deas had no modifying effect.

To study the situation we muet necossarily $g^{\circ}$ back hundred years before the time of Milton's divoroe tracts to the celobrated case of King Henry VIII. Although the problem of dirorce had existed previous to the time of Henry, his case stimulated thought and controversy on the question. When the Anglican church separeted from the Roman Catholic, the reform of marriage and divorce laws was attempted for the first time in Bng1and. In accordance with the act of 25 Henry vil, 68 . 19 (1534), a committeo was appointed to draw up "a new platform for the occlesiastical doctrine and disolpline of England." In the meantime, however, it was provided that: - suche canons constitucions ordynaunces and synodels provynciall being allredy made, which be not contraryant to the lawes statutes and customes of this Realme nor to the damage or hurte of the Kyngea prerogetjve Royall, shall mowe styll be used and executed.I

I. Ib1d., p. 61 . 
These loose terms ceused many evil practices in the divorce courts. The dirorces obtained were usually annulments of marriage founded upon some pretext of contract. Lecordingly in 2540 the act of 32 Henry vili, ca. 38 was passed to stop wholesale annulments. The preamble to this act expressed the same opinions as were proclaimed in parliament in 160\%. Both acto wore familiar to Milton in his later study of the divorce question. 1

The woakness of this act was in its last sentence: "And that no reservation or prohibition, Godds lew excopt, shall trouble or imoche anny mariage without the Leviticall degrees." The "Goddis Iaw except" was the phrase with which the church maintained power, and the act had no actual application.

According to Milton, howerer, the committeo previously appointed was at work. On it were such prominent men as Archbishop Cranmer, Peter Martyr, Walter Haddon, and sir John Cheoke. The effect of the Reformation and Luthor' teaching is clearly shown in their rocommendations: (1) abolition of separation a mensa et thoro, (2) real divorce allowing remarriage for the innocent party for adultery, desertion, and other 111 usages,

I. Ib1d., p. 62. 2. Ioc. cit. 
and (3) the placing of husband and wite on equal footing. That this committeo, as reported by Milton, was appointed by Edward is declared erroneous by Powe11. 1 With the death of Henry the bill, the Reformatio Legum Ecclesiagticarum, was defeated under Bdward by the House of Commons. It was the belief merely of the leaders of the day and not of the rank and file of the kingdom. sfter its defeat no further advance was made. The act 32 Henry vili, ca. 38 was reperled and repassed alternately in the star Chamber, but, as usual, the church escaped under the loop hole, "Goddis law except." Edward's efforts for divorce reform consisted in bringing Martin Bucer as a professor of Divinity, 2 and Fagius as a professor of Hebrew to cambridge, and repealing the impractical law of Henry.

Hence the attitude of the Churoh of ingland remained abstantially the same. Henry's committeo was onlightened, but its work was abolished by the House of Commons, thus onding any reform in the church up to the time of Milton.

Under Elizaboth the church held fast to its old prinoiples with the High Commission Court under Whitgift. The courts indiscriminetely granted annulments and 
opparations a monea et thoro which were imediately used by the plaintiffs as actual dirorces.

In 1603 a now canon was passed to the effect that "parties shall not marry during the lifetime of both and parties must give good and sufficient security that they will not broak this agreement." Ih The canon did not affect the situation because with forfeiture of the securfty the law was satisfied, and the individual was freo. Such was the legielative history of the attempted reform of ditoree in the Church of Ingland. The administrative angle was found in the oclesiastical courts. These ranged from the Archdeacon's, to the court of High Comissions, to locel courts called by Baoon "mere shops," to which people of mesger circumstances went for dirorce. 2 But it must be remembered that these courts were of the church, and in the church, and whatever abuses they practiced were in the name of the church, case parallel with the Roman Catholic doctrine and administration.

II. AMONG THE PURITANS AND INDEPENDENTS

The attitude of the Puritan-Independent $8 \mathrm{chool}$ dereloped along a different course which may roughly be 1. POFeII, op. c1t.. p. 84. 2. Ibia., $\mathrm{p} \cdot 66$. 
divided into three period as their power waxed rather than wand with a growing membership. From the time of Henry VIII until the consorship of the press by Iand ca. 1610, attacks upon the Anglican refusal of remarriage after diforce to the innocent party, and upon the corraption and abuses of the courts grow in intensity. Then followed a period of stlence nnder laud, lence broken only by occasional surreptitiou pamphlete, and hints In domostio conduct books as to subjeots rital to the people. With the fall of Iaud in 1641 the full force of the suppression burst forth with the dirorce program and Multon's pamphlets. 1

The mein causes of disagreoment were on two points. One point was the remarriage of the innocent party after divorco, the earliest and most consistently mot cause of argument. The second was the abuse of the granting of annulments. These annulments wero based on impedimente to marriage which were noither clearly defined nor adequately administered. This culminated in attecks on the occlesiastical courts. Milton's Smectymuns was an example of one of the later attacks in which he showed his hatred of the corruption of the courts.

The Puritan-Anglican controversy was pursued

1. CI. post, p. 42 . 
both from the pulpit and in the press. The partic1pante included high churchmen, domestic conduct book writors, and pamphloteers. From the material availablo on the subject, certain works are outstanding and will be briefly reviewed.

Chronologically close to the first committeo of Henry, formed in 1534, was the work of the first important Puritan, Bishop Hooper, who in 1550 published the Declaration of the Ten Commandmente. I In 1 t he followed the German ideas of divorce for adultery. Significant is the fact that he adrocated equal footing for men and women as did Henry's committeo. The Puritans held their enlightened principles, while the Anglican church did not incorporate them into their doctrine. Becon in 1562 wrote a Boke of Matrimong which stated that "Christians may put away thoir wives for no fault either of body or mind adultery only excepted, ' $n^{2}$ and attacked the Anglican church for not allowing remarriage. To support his theory he quoted Erasmus, Iuther, Bucer, Calvin, Melancthon, Bullinger, Peter Martyr, Musculus, Lacarius, and Brentinus who 811 believed that the innocent party should be ellowed to remarry.

1. POWeII, Op. OIt., p. 14.

2. Ibid.. p. 75 . 
Robert Brown, who in 1582 published The life and manners of true Christians, 1 made a significant contribution. He upheld the civil magistrates over the prelates and in reality started the Independents' movement against ecclesiastical jurisdiction.

In 1578-73 Cartwright and Whitgift indulged in a series of controvergial pamphlets. Cartwright in c. 1573 In his Reply to an Answer ${ }^{2}$ upheld Brown's prinoiples and took exception to mitgift's statement that there was no distinction between civil and eoclesiastioal jurisdiction because both were executed by the Queen. Th1s was in support of the new dirorce theory on the basis of the fact that marriage was considered a civil affair. The disagreement over the prelacy reached greater proportions than that over divorce, and dwarfed the latter isaue erentualiz.

Domestic conduct books, the Emily Posts of their dey, contained information and advice on household subjects. The writers were usually close to the people in thought and it show a decided trend toward puritan ideals when Henry Sm1th in 1591 in A Preparation to Marriage declared, "The disease of marriage is adultery, and the medecine heerof is Divorcement. 3

I. Ibia., p. $7 \%$

2. IbId., p. 78 .

3. IbIa., p. 75 . 
William Perkin's Christian oecomomie, ${ }^{1}$ written in 1590 in Iatin and translated into Finglish in 1609, was not controversiel in character. This work, knom to Milton, and referred to by him in the firet divorce tract, 2 gave a general picture of the situation existIng at that time. The impediments to marriage, the besis for aunulments, were still in operation and were not opposed in theory by the Reformed church at that t1me. There were four grounds for divorce recognized by the Puritans: (1) desertion, (2) malicious dealing, (3) long ebsence, and (4) adultery. There was no sex discrimination in their conception.

While the emphasis in the controversy between the Puritans and Anglicans was on the question of the power of the courts, in the last part of the century the divorce question again rose. Since the puritans accepted the validity of the impediments, the quarrel arose over the separation a mensa ot thoro vs. complete divorce with remarriage. On the Anglioan side sermons were thundered from the pulpits of Bunny and Dore upholding separation from the basis of scriptural interprotation and patriarchial authority. 3 In 1597 John

I. IbId., p. 19.

2. CI. post, p. 67 .

3. Powoli, op. cit., p. 81. 
Rainolds wrote a Defense of the Reformed Churches which was not published unt11 1609 because the Arohbishop of Canterbury thought it contained dangerous doctrine on the subject of divorce, the dangerous doctrine being defense of remarriage after dirorce.

About 1610 this was the situation in England. The Puritans had finally departed from the Catholie theory on which the Anglican was established by narrowIng the fleld of annulments to the old Ievitical degrees of relationship. Thoy had also narrowed the German liberal principles of divorce to desertion and adulterj. The Anglican charch had reestablishod the law of 32 Henry $\nabla 111,08.38$ where tho impodiments wero limited to "Goddis Ian except." 2 Separations a mensa et thoro were granted and acted upon as real dirorces by erading the security required by law.

From the time laud gained control, and until his fall in 1641 his censorship orer the press practically eliminated printed opinions on controversial subjects.

\section{IMMEDIATE BACKGROUND FOR MIITON}

By 1643, however, the pioture had ohanged. The Puritan-Independent movement had grown so that they

1. IbId., p. 82.

2. supra, p. 20 . 
wore gaining command of the political situation, and Iaud was imprisoned in the Tower. They were actively combatting the idea of prelacy in press and pulpit. The Assembly, formed to consider Puritan church policy, was moeting for the first time since laud had dominated the situstion. Many forms of church policy wero adopted at this time including the following platform on divoroe. Prominent points were grounds of desertion and adutery only, and the recognition of civil courts.

Marriage ought not to be within the degrees of consanguinity or affinity forbidden in the word, nor can such incestuous marriages ever be made lawful by any law of man or consent of parties... Adultery or fornication being committed after a contract boing detected before merriage, giveth just occasion to the innocent party to dissolve the contract; in the case of adultery after marriage, it is lawful for the innocent party to sue out a divorce, and after the divorce, to marry another as If the offending party was doad.

Nothing but adultery or such wilful desertion as can be no way remedied, by the Church or Civil Magistrate, is carse sufficient of dissolving the bond oI marriage, wherein a publike, and orderly course of the proceeding, is to be observed, and the persons concerned in it not left to their own wills, and discretion to their own case.1

Against this background, and in this same year, John Milton published the Doctrine and Discipline of Divoree, easily the most advanced document of its time.

I: Powell, op. cit., p.88. 


\section{CHAPTER III}

\section{MIITON'S PARTICIPATION IN DIVORCE DISCUSSIOH}

The hundred years before Milton sumarized in the procoding chapter showed remarkable development in divorce theory in Fingland. The original liboral princlples of the Anglicans and the Puritans had boen narrowed so that the established policy of neither group was as broad as leaders had tried to make it in the past. However in 1643 the discusaion was again open, and the problem of this chapter is to show why Milton bocame interested, and to what extent he participated in 1 t.

The chapter consists of five sections: (1) Milton's interest in divorce: intellectual or personal? (2) Milton's background, (3) the roopening of divorce discussion, (4) other dirorce contributions, and (5) popular and literary references.

I. MIITON'S INMEREST IN DIVORCE: INTELLECTUAI OR PERSONAL?

Whon therefore I perceived that there were throe species of liberty which are essential to the happiness of social life - religious, domestic, and civil; and as I had already written concerning the first,

- and the magistrates were etrenuously active concerning the third, I determined to turn my attention to the second, or the domestic species. As this seemed to involve three material questions, the conditions of the confugal tie, the education of the children, and the free publioation of thoughts, I made them 
objects of distinct consideration. I explained my sentiments, not only concerning the solemnization of marriage, but the dissolution, if circumstances rendered it necessary; and I drew my arguments from the divine law, which Chriet did not abolish, or pablish another more grievous than that of Hoses. I stated my own opinions, and those of others, concerning the exclusive exception of fornication, which our illustrious selden has since, in his Hebrew Fife, more copiously discussed; for he in rain makes a vaunt of liberty in the senate or in the forum, who languishos under the vilest servitude, to an Inferior at home. On this subject, therefore, I published some books which were more particularly necessary at that time, when man and wifo were often the most inveterate foes, when the man often stajed to take care of the children at home, While the mother was seen in the camp of the onemy, threatening death and destruction to her husband. I

This passage, taken from the Second Defonse (1654)

was a pert of the autobiographical self-defense included by Milton in that work. Here it appears that the discussion of divorce was part of a well developed program of writing to aid Reformation in England. It was on a high intelleotual plane, and no reference was made to any personal intereat in the problem. This statement of Milton's, however, has not been ontirely accepted by soholars. Personal elements in his life have been considered as also affecting his interest in the divorce problem.

- The division among scholars has dereloped as new

1. Hanford, James H., A MfIton Handbook, Third Edition (New York: F. S. Crofts and Co., 1939), pp. 43-44. 
data pertaining to Milton's iffe have been discovered. David Masson in his Iife of John Milton, 1 Mark Pattison in Mllton, ${ }^{2}$ Waltor Raleigh in Milton, 3 Chilton Powell in English Domestic Relations, 4 James H. Hanford in A Milton Handbook, ${ }^{5}$ and Denis Saurat in Mliton: Man and Thinker ${ }^{6}$ have been the chief Milton scholars who have advanced conflicting theories concerning the complete background of the divorce tracts. Masson bolleved Milton's reasons for entering the dirorce discussion, despite the passage in the Second Defense, were entirely personal and caused by a dometic situation. Milton's wife left him to visit her family and refused to return. Masson, using a fictionalized method, presented a realistic picture of Milton's unhapp brooding which resulted in the Dootrine and Discipline of Ditorce and the ensuing scandal and gossip among his contemporaries. He believed Phillips's date of June, 1643 for the wedding to be inaccurate because Milton would neither have had time to compose

\footnotetext{
1. Masson, David, Life of John MIton, Vol. III (London: Macmilian and co.. 1873).

2. Pattison, Mark, Milton (John Morley, editor, English Men of Letters Series; Now York and London: Harper and Bros., 1901).

3. Raleigh, Walter, Milton (New York and Iondon: Macmilian Co., ig00\%.

4. Powell, op. cit.

5. Hanford, op cit.

6. Saurat, Denis, Milton: Man and Thinker (New York: The Dial Pross, T225).
} 
the pamphlet and have it published after his wife left, nor could he reasonably have composed it with his wife

in the house.

Yet it is the other that one would wish to be true, and that fit in most neturaliy with the facts as a whole. That version is that Milton, good-naturedly and perhaps taken by surprise, allowed his wife to go home for two months at her own request, or at the request of her relatives, before he had been three months married, and that it was the insult of her non return that revealod to him his mistake in her, and drove him into his speculations about diroroe. Only, then, we repeat, Phillips's dating of the marriage and its incidents requires amendment.

Mark Pattison believed also in Milton's personal

interest in the problem but thought that the cause of his interest was the utter stupidity of his wife and his disappointment in matrimony bocause of his wife's rofusal to consummate the marriage.

His poet's imagination had invested a dull and common girl with rare attributes moral and intellectual, and had pictured for him the state of matrimony as an earthly paradise, in which he was to be secure of a response of aftection showing itgelf in a communion of intelligent interests. In proportion to the brilliance of his ideal anticipation was the fury of despair which came upon him when he found out his migtake.2

The suggestion, which I believe was first made by 2 writer in the sthenseum, is that Milton's young wife refused him the consummation of the marriage. The supposition is founded on a cortain passage in Milton's pamphlet.

If the early date of the pamphlet be the true date; if the Doctrine and Discipline was in the

1. Lesson, op. oit., p. 47

2. Pattison, op. cit., p. 53 . 
hands of the public on August 1 ; if Milton was brooding over this seething egony of passion all through July, with the joung bride, to whom he had been barely wedded a month, in the house when he was writing, then the only apology for this outrage upon the charities, not to say decencies of home is that which is uggested by the passage referred to.1

Walter Raleigh believed also that the diroroe tracte were written because Miton was unhappily married, but thought the greatnoss of his character gave him an overview and intellectual interest not common to the ordinary man.

Thet one principal cause of the rupture has been rightly divined, by Mr. Mark Pattison and others, is probable. . .

But al though the hurt ho had auffered, in his most susceptible feelings, gires eloquence and plangency to his dirorce pamphlets, it was not merely to voice his eufferings that he wrote those pamphlets. - he was a citizen first, a poet and an unheppy man afterwards. - . Thus even in this most personal matter he pleads, not for himself.
but for the commonweal.

That Milton's interest in the cause of dirorce was chiefly intellectual was the contention of fowell who presented a realistic conception of Milton's attitude. He believed that becanse of the time element inrolved, only a previous interest in the divorce problem could have given Miton adoquate time to plan and writo the first dirorce tract. Powell emphatically denied

- that his wife's desertion had any bearing on the situation, because desertion was already a recognized ground

I. IbId., p. 56.

2. Raleigh, op. eit., pp. 48-49. 
for dirorce.

The Doctrine and Discipline of Dirorce was planned in 1642, as lilton clearly states, was published on or before August 1,1643 , and had no connection whatever with his own domestic life. The theories as to Milton's disgust with his young wife, and his disgruntied attitude toward the marriage state (he who was thrice married), the scenes depicted as resulting therefrom (including, alas, such triumphs of the imagination as Masson's picture of the parting of husband and wife and his account of the excitement caused in the lobby of the House of Commons by the scandal), and finally the calumnies cast upon this unromantio and rather humdrum couple, might well be ommitted from future biographies.I

Hanford, in his early oditions of a Milton Hendbook ${ }^{2}$ agreed with Powell to a certain extent because of the fact that Milton had interested himself in the general philosophy of marriage as early as the Horton period. In the Commonplace Book under Matrimonium there are many entries of reformed opinion on merriage. Hanford further says in a special article:

There are, to be sure, no diroroe entries in the period but l6th century polygamiets (for example ochinol were aleo divorcers, and Milton's later opinion is but the logical outcome of his whole early trend of mind. 3

Additional weight is also lent to this theory by the testimony of the Anonymou Blographer.

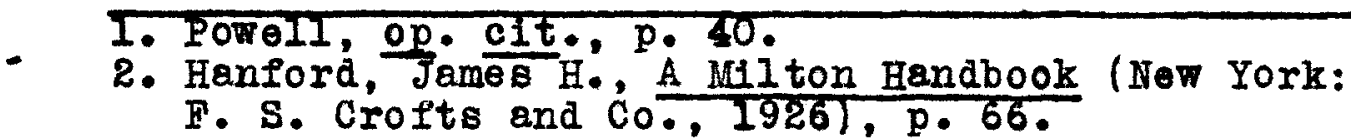

3. Hanford, James H., "The Chronology of Milton's Private Studios," PMIA, XXXIV (1921), 294. 
He thought upon divorce, that he might be free to marry another; concerning which he was also in treaty. The lawfulness and expodience of this, duly regulate in order to all those purposes for which marriage was first instituted; had upon full consideration and reading good author been formerly his opinion; and the necessity of justifying himself now ooncurring with the opportunlty, aceptablo to him, of instructing others in a point of so great concern to the peace and preservation of families, and so likely to prevent temptations as woll as mischiefs, ho first writ ...1

But like the Anonymous Blographer, Hanford tempered Powell's strictly intellectual motives with Milton's personal life. He thought that some woight should be attached to his wife's failure to return bat stated, "It is an open question how much further one oan go in tracing the detalla of Milton's experience in the ostensible impersonal discussion." 2 The pondulum swung the other way, however, with the publication of Saurat's Milton: Man and Thinker. He carried still further Pattison's theory that Mary Powell's refusel to consummate the marriage was the resson for the Doctrine and Discipline of Divorce by picturing wilton as a man of passion. He quoted from the divorce tracts to support his thesis that MAlton married because he was carried away by physical passion and that when his wife refused to consummate the

1. Povell, op. cit., p. 40.

2. Hanford, luliton Handbook, Third edition, pp. 90-91. 
marriage, ho wos wrecked in "sensual whirlpools."

But the young women's refusal gave Milton the ifrst great shock of his life. He saw at once his Irreparable mistake. He found himself placed in dilemma intolerable both to his purity and his pride. Physical passion had boen roused in him, and then thrarted; he was not really marriod, and now he was forbidden to get married. His highest ideal, that of love as a harmony betweon body and spirit, was at once shattered and soilod. And tho cause of this painful degradation was the blind impulse of the flesh. Hence the anger ageinst the mistrust of the flesh which remained, under his more liberal general 1deas, all through his $11 f^{\circ} \cdot 2$

Between these two riews of Milton's motives, intellectual or personal, lies a middle course which seems a logical one. The study of Burns Martin, The Date of Milton's First Marriage, 3 is the latest bit of blographical material to be uncovered. It proves rather conclusively that the marriage date must have been 1642 which explodes the idea that the divorce tract was written with Mary Powell in the house. 4 That would remove the necossity of the hypothesis of the refusel of consumation, and so invalidate many of the argaments for the purely personal motive. Yet a year's absence on the part of his wife would form too strong a link to

1. Sanrat, op. cit., p. 55.

2. Loc. cit.

3. Martin, Burns, "The Date of Milton's First Marriage," Studios in Philology, XXV (1928), 457-462.

4. Beoause of the difilculties of communication caused by the war in 1643, it must have been 1642 that Milton's messenger was sent to the Powell home near oxford. 
the time of the appearance of the divorce tracts to be mere coincidenoe. In the latest odition of Hanford's A Milton Handbook, he accepts the new date of marriage and suscribes to the theory that personel motives formed the incentive for Milton's writing on subject in which ho had long been interested.1

\section{MIITON'S BACKGROUND \\ A. ATTITUDE TOWARD WOMAN}

Diroroe itself was not montioned in Milton's writing previous to the divorce tracts, and wo find 1ittle interest in the other closely related subject, that of women. In connection with the latter he stresses two widely differing viewpoints in his writings before 1643. The first is that of the courtly tradition, the literary tradition of his day, and the second that of the Importance of the chastity of youth. Neithor of these points of view indicates a dooided trend, because if his works are taken in chronological order, first on and then the other is found.

In exposition of the courtly tradition wo find Milton in the First Elegy to Diodati seoing "groupes of maidens go by, breathing soft flames," 2 and in the

1. Hanford, A MIton Handbook. Third edition, pp. 89-90. 2. Milton, John, A Student's Milton (Frank A. Patterson, editor, New York: H. S. Crofts and Co., 1931), p. 86. 
Serenth Elegy falling in love on sight and being left in mourning when the lady vanished. H1s college days brought forth a series of sonnets to one Emilia, written In Itelian, "a language whereof love is proud," ${ }^{l}$ employIng the concolts common to the Renaisance poets. All these references show that this work did not so much touch Milton's spirit as they gave him exercise in the courtig tredition. A momber of the bourgeois, he found evident pleasure in employing the tradition of the fashionable class.

It is in the other viewpoint toward women, that of the necessity of the chastity of youth, that we find the Milton we are to know later. In Peredise Lost ho expresed the opinion that woman was made for man, and that man was suporior. ${ }^{2}$ This bollef was antioipated in h1s early attitude toward his male friends. In his letters and elegies to Diodati there is an ease and freodom of expression that seems to imply that that companionahip was sufficient for him. Two of his greatest oarly works, Damon's Epitaph and Lroidas, were occasioned by the death of his friond and are far superior to the exercises in courtly fashionable lyrics. In thought they strike much more deeply. In comas he says that through 
virtue and chastity which "alone are free" can one olimb "Higher then the Spheary chime." 1 Both Damon and Iyoldas are honored in heaven by songs of saints beoause of their virginal youth.

So wo find mition, up to the divorce tracts, either honoring women in a way fashlonable at the time, indicating nothing of his later attitude, or putting a great emphasis on chastity, probably through a natural Inclination because of the adequacy of his male companionship. This latter attitude was really negatire. The emphasis on purity may hare been caused in part also by his great determination to prepare himself for an intellectual life.

That the unfortunate experience with his wife made a deep impression on Milton cannot be denied. No metter whet theory one holds about his writing the divorce tracts, the fact that the pamphlets mark a distinct change in his attitude toward women is quito clear. All mention made by him of women previou to 1643 was in the oourtly tradition. No trace of that is found either in the divorce tracts or in his later writings. Women became to him realistic creatures of flosh and blood. In his most telling descriptions,

I. IbId., pp. 66, 67. 
after his experience with h1s wife, his pictures of women are most unflattering. Diatribes appear throughout the divorce pamphlets against phlegmatic and sluggish women. ${ }^{1}$ In Paradise Iost Eve is not even honored by a great sin, but is betrayed through flattery. ${ }^{2}$ Her shallowness is her outstanding attribute when Milton shows her to be self willed, selfish, and disobedient.

\section{B. MIIMON'S MARRIAGE}

John Nilton's famlig had earned his gratitude by leaving him free to study at the university and Horton. It was after his trip to Italy that ho first seemed to realize that there was a necossary place for himself in the world. It was then thet he wrote his ant1-prelatical pamphlets and started his school, and it was after he became an established citizen that it occurred to him that as such he should have a wife. John Milton's mode of life in 1642 seems most serious and philosophical. At the age of thirty-four he had ostablished his school and begun the development of his Reformation program, that of championing the cause of religious, domestic, and civil liberty. For emusement, according to his nephew's account of his life,

1. Cf. post., pp. 59, 109.

2. Paradise Lost, Book 9. 
he occasionally would go out with friends, but these infrequent diversions must not have formed a very satiefactory mode of lifo. John Milton, schoolmaster, must have felt that it was in keeping with his position to have a wife.

Here the long arm of coincidence reaches out. In 162\%, when Milton was a student in Cambridge, his father had advanced \pm 500 to a certain Colonel Powell on mortgage for his son's use. Milton in 1642 must have gone to see about this bad debt and met Mary who married him and returned with him to his home. After a short stay she begged leave to visit her family again. How dreary the school must have seemed after her gay country life! If the date of 1642 is correct, and it seoms substantially proved, ${ }^{2}$ we have ample time for Milton to await his wife's return, send for her, have his messenger rejected, to brood upon separation and divorce, to realize the inadequacy of civil laws and religious customs, and finally to write the Doctrine and Discipline of Divorce by the summer of 1643.

\section{SUMMARY}

There we have a fusion of the intellectual and personal motives and explanation of both. Enough 
evidence exists on the side of either saurat or Powell to justify either. John Milton was incapable of actions from purely personal motives. He was not so muoh the man of passion Saurat tries to make him, nor was he inhuman and entirely intellectual. Breaking through hio logicel reasoning time and time again his expression shows that he felt deeply on the subject. Had his interest been entirely personal, however, his diroroe could have been obtained without recourse to pamphleteering, because among the Puritans desertion was a recognized ground.

Another man might have used all the means open to him to become aivorced or separated according to the existing laws or mores, or else accepted a bad situation as such, but not Milton. That concernod him must concern other men, and what concerned other men's rights was a cause to be upheld, a wrong to be righted, a matter for aiscussion, pleas, or invective if necessary. John Miton's personal marital troubles could be righted only in the best interest of ell Englishmen.

\section{REOPENING OF DIVORCE DISCUSSION}

One point not previously mentioned in any disoussion of Milton's intellectual interest of the divoroe problem is the effect on him of the undoubted interest 
of the time. With the dethronement of Iand in 1641 controversial questions could be discussed more openly. and the fact that dirorce had been a muted topic has been explained in the last chapter. The fact of the adoption of the dirorce resolutions by the Assembly bears out this point. ${ }^{1}$ With such a statement an act of the Assembly of 1643, surely divorce must have been an object of discussion among Milton and his friends. It connot be mere coincidence that the first definite divorce statement of the Puritan party and Milton's first tract appeared at the same time.

The storm of disapproval centered on the first edition of the Doctrine and Discipline of Divorce in Auguat, 1643 came from two sources: Anglicans who were neturally opposed to Reform doctrine, and the Puriten whom Milton had previously supported in his pamphlets against the prelacy. The fact that ho had extended the grounda approved by them of desertion and adultery to incompatibility made them consider his doctrine dangerous and fanat1c. Therefore he hastened to strengthen his position with what authority he could find. By February, 1644 many weighty names and arguments had been inserted in the Doctrine and Discipline of Divorce when the second edition was presented to Parliament.

1. Supre, p. 28. 
Milton evidently expected his theories to be incorporated in the reform divorce platform because he included the Assembly in the introduction to parliament. That they did not concur with his opinions is a matter of record. In the Introduction to the Judgment of Martin Bacer Milton spoke of ". . those who have stood now almost this whole year clamoring afar off... . ${ }^{l}$

At that time lifton realized that there was no hope in that body for support, and his other dirorce contributions were addressed to Parliament only.

They fell as violently upon his pamphlet concerning marriage and divorce as though they had never heard of the support he had given Smectymnuus. He for his part ceased to look to presbyterianism for the realization of his Utopian ideals.2

Thus it oan be seen that the downfall of laud, the dirorce platform of the Assembly, and the controversial theories introduced by Milton reopened the discussion of dirorce in England in 1643.

IV. OTHER DIVORCE CONFRIBUTIONS

The Ione stand taken by Milton on the subject of divorce, that mutuel consent and incompatibility were sufficlent grounds, meant that it was necessary for him

1. MiIton, op. cit., p. 631.

2. Haller, Wiliam, The Rise of Puritanism (New York: Columbia University Press, 1938), p. 362. 
to find weighty support in the fiold of reforma thought. Therefore other publications followed the Doctrine and Discipline of Divorce.

The first to strengthen Milton's position was 8 summary of Martin Bucer's arguments. Martin Bucer was a theologian imported by Archb1shop Cranmer and Edward VI to aid the cause of Reformation in England. He was shown much favor by Edward and was consulted about the revision of the Book of Common Prayer. In Mil ton's treatise, The Judgment of Martin Bucer touching Divorce, taken out of the second book entitled nof the Kingdom of Chriet" (1644), ho advancod no new arguments but added a considerable amount to his standing. Before the introduction to Parliament, Milton published a long list of testimonials to Bucer's worth, written for the most part by prominent reformers.

The Judgment of Martin Bucer did not serve its purpose and add to Milton's prestige among the puritans. It was ignored by Herbert palmer when he preached a spocial sermon before a joint meeting of the two houses of Parliament on August 13, 1644. He accused Milton of impudence in dedicating an unlicensed pamphlet on such a subject to parliament, and called the book "wicked and deserving to be burnt."1

1. MIton, 으. it., p. 649. 
The eermon was the equivalent of our present day newspaper headines and aroused the Stationers who were 11kely to be injured by such publicity given to unlicensed pamphlets. Therefore on August 25, they petitioned Parliament to take action against the publication of unlicensed and unregistered literature. They wanted a more strict enforoement of the act of 1643 which required the licensing of all publications by an offloial consor. Milton resented deeply any censorship of what he felt to be the right of all men, that of free speoch. In defonse of his personal liberty, whlch was ondangered if the licensing act were enforced, and also in line with his acknowledged plan of action in his reformation program previously discussed, he suspended his work on the dirorce pamphlets and championed the cause of a free press and Preo spoech. Areopegitica, published without license in November, 1644, is his best known prose work. In defense of a Ireo press he said:

- . and that a fool will be a fool with the best book, yea, or without book; there is no reason that we should deprive $a$ wise man of any advantage to his wisdom, while we seek to restrain from a fool that which being restrained will be no hindrance to his folly. 1

In 1645 the two final dirorce tracts appeared, Tetrachordon and Colasterion. Tetrachordon, the longest 
of the pamphlets, was written for the same purpose as the Judgment of Martin Bucer. It contained his final arguments in answer to the theologians and their objections to his interpretation of the scripture. It was another desperate effort to harmonize conflicting Biblical quotations, and its name was taken from tho four chief scriptural passages referring to marriage or divorce. Milton stated his divorce thesis once only, in the Doctrine end Disoipline of Divorce. All his other contributions were in the line of justification or attack. He delivered a bitter attack on pelmer and the offending sermon in the introduction, in which he denounced both him and Featley, who had, in tract, Dippers Dipt, criticized Milton also.

The last of the divorce tracts, Colasterion, named the tor ture chamber, was published at the same time as Tetrachordon, but is an entirely different sort of writing. Whereas in the latter dignified prose set forth scriptural arguments, and the weight of the names of prominent reformers reinforced his arguments for divorce, Colasterion is merely a blasting of an opponent, who, as Milton said, was really unworthy. This personal attack was caused by an anonymous publication which attacked the first edition of the Doctrine and Discipline 
of Dirorce. Milton inquired about the document and found it to be the work of a serving man turned solicitor. Its title was:

An Answer to a Book, Instituted, The Doctrine and Discipline of Divorce, or a plea for Ladies and Gentlemen and all other Married Women, againat Divorce. Wherein Both Sexes are Vindicated from all bondage (sic) of Canon Law and other mistakes whatsoever: And the Unsound Principles of the Author are examined and fully confuted by Authority of Holy Scripture, the Iaws of this Iand, and Sound Rearon.I

By making this work the butt of coarse ridicule, Milton adranced the divorce arguments little. He felt, probably, that hio work had been sufficiently well done in his previous works. Instead, he merely repeated the arguments of his opponent, took vengeance in heavy satire, and indulged in a "talent for sport." 2 Masson enthusiastically comments thus:

Never was poor wretch so mauled, so tumbled and rolled, and kept on tumbling and rolling, in ignominious mire. Milton indeed pays him the compliment of following his reasonings, restating them in their order, and quoting his words; but it is only, as it were, to wrap up the reasoner in the rags of his own bringing, and then kick him along as a football through a mire of mud.3

In the two sonnete associated with the divorce tracts, the beginning of Nilton's disappointment in his countrymen is evident. In sonnet XI (1645-6) he complained about the illiteracy of his age.

1. Masson, op. cit., p. 299 .

2. Ibid., p. 320 .

3. Ioc. cit. 
A Book was writ of late call'd Tetrachordon;

And wor'n close, both matter form and stile;

The subject new: it walk'd the Town a while, Numbring good intellects; now seldom por'd on.

Cries the stall reader, bless us! what a word on

A title page is this! and some in filo

Stand speliling fals, while one might walk to Mile-

Fnd Green. Why is it harder Sirs then Gordon,

Colkitto, or Macdonnol, or Galasp?

Those rugged names to our like mouth grow sleek

That would have mede Quintilian stare and gasp.

Thy age, like ours, 0 Soul of Sir John Cheok,

Hated not learning wors then Toad or Asp;

Whon thou taught'st Cambridge, and King Edward Greok.

Sonnot XII, although couched in general terms,

goe 8 hand in hand with colesterion.

I aid but prompt the age to quit thoir cloggs

By the known rules of ancient libertie,

When strait a barbarous noise environs mo

Of Owles and Cuckoes, Asses, Apes and Doggs.

As when those Hinds that were transform'd to Proggs

Raild at Iatona's twin-born progenie

Which after held the sun and Moon in fee.

But this is got by casting Pearl to Hoggs;

That bawle for freodom in their sencoless mood,

and still revolt when truth would set them free.

Iicence they mean when they cry libertio;

For who loves that, must first be wise and good;

But from that mark how far they roave we see

For all this wast of wealth, and loss of blood.

These were Milton's closing remarks on the divorce

question. From a statement of doctrine and new theory,

the discussion had deteriorated into an exchange of per-

sonalities. Masson says:

With the sonnets, written after his wife's return, he dropped the divorce argument, or at least $1 \mathrm{tg}$ public prosecution. That he did with a certain reluctance, and in no spirit of recantation. 1

1. Masson, op. cit., p. 461 . 
The only other reference to divorce was made in the Christian Doctrine, Chapter X (1655-1660), in whioh he reviewed the whole subject of merriage and divoree. In no way were his 1deas changed from those he had held many jears before.

\section{POPULAR AND IITERARY REFERENCES}

The popular reaction to the divorce tracts can only be judged by occasional releted remarks. In sonnet XI Milton said:

The subject new: it walk'd the Town a wh1le Numbring good intelleots; now seldom por'd on. Yet while the "subject walked" there mast have boen much excitement. Alroady mentioned are the pamphlets which he answered in Colesterion, ${ }^{1}$ Dippers Dipt, and palmer's sermon. 2

For other contemporary reaction my source is Masson's Iife of John Milton. He quotes James Howell, a letter writer, as saying this of Milton:

But that opinion of a poor shallow-brained puppy, who, upon any cause of dissatisfaction, would have men to have a privilege to change their wives, or to repudiate them, deserves to be hissed at rather than confuted; for nothing can tend more to usher in all confusion and beggary throughout the world . . . 3

Bishop Hall in Cases of Conscience sald:

1. supra, p. 47 .

2. Loc. c1t.

3. Masson, op. cit., p. 62 . 
I have heard too much of and once saw, a licentious pamphlet, thrown abroad in these lawless times in the defense and encouragement of Divorces... Woe is me! to what a pass is the world come that a Christian, pretending to Reformation, should dare tender 80 loose a project on the pubilic.1

Masson lumps other criticismb thus:

"These I term Divorcers," says old Ephraim (paget), "that would be quit of their wives for slight occasions"; and he goes on to speak of Milton as a representative of the sect. Featley had previously mentioned Milton's Dirorce iract as one of the proofs of the tendency of the age to Antinomianism, Familism, and general anarchy; and Edwards and Bailile followed in the same strain. Milton's Doctrine of Divorce, it thus appears, had attracted attention, and had perhaps gained some following. Among the six caricatures of notable sects on the title pages of Paget's Heresiography is one of "The Divorcer" - 1.e. a man, in an admonishing attitude, and without a hat, dismissing or pushing away his wife, who has her hat on, as If ready for a journey, and who is putting her handkerchief to her eyes.

The Edwards mentioned by Masson had in his

Gengroena accused Milton of influencing a certain Mrs. Attaway, who had obtained a divorce.

There our record of contemporary reaction ends.

The only literary reference after that was in the Restoration drama. Farquhar wrote a play, Beaux' stratagem, which was performed in 170\%. Larson, in a study of Milton's influence on Farquhar, comments:

Farquher had boen reading Milton, and was deeply under his influence; so great, in fact, was that influence, that without it, Farquhar's last and greateat play could not have been written as we know

1. IbId., p. 63 .

2. Ibid.. p. 155 . 
1t. The divorce ideas of our dramatist assume a seriousness greater than they otherwise might have done, when we know that their source lies in documents so profound as those of Milton. 1

some of the 1deas that he adopted were: mutual consent of the parties, ruir and suicide if they wero 111 mated, that divorce was a secret and private affair, and that nature was the first law-giver. parta of his dialogue are taken directly from the divorce tracts.

In this chapter I have given Milton's reasons for writing the divorce tracts, a picture of Milton'a Iife prior to 1643, a mention of all thet the term "divorce writings" includes, and contemporary and Iiterary reaction to them. A summery of their content has been reserved for the next chapter. 
PART II

CHAPTSR IV

\section{SUMMARY OF DIVORCE TRACTS}

Up to the time of John Milton, the arguments for divorce had been made on the bagis of social good only, had not considered the individual, and had boen developed mainly on physiological grounds. In his day the most daring adrocates of divorce had merely oxtonded the Catholic grounds of separation a mense et thoro: adultery, desertion, and danger to body or soul, to the complete divorce allowing remarriage. Milton, in a tremendous forward step, reached the modern basis of scientific social thought, the psychological approsch to the individual in the accomplishment of social good.

The second part of this the sis consists of a summary and analysis of Milton's divorce writings which Include: The Doctrine and Discipline of Divorce (164243), The Judgment of Martin Bucer (1644), Tetrachordon (1645), Colesterion (1645), and Chapter $X$ in the Christian Dootrine $(1655-60)$. Chapter IV is a running summary and analysis of Milton's writings on divorce. Chapter $V$ examines the method and basis of Milton's argament. 
I. DOCTRINE AND DISCIPIINE OF DIVORCE (1643-44)

Milton's first pamphlet on divorce was the Dootrine and Disclpline of Divorce. The second edition (1644) will be used here as source material because for my purpose the genesis of Milton's thought is not an important factor. The second edition, presented to parliament, contains the same material as the first with the arguments amplified and more clearly stated. It contains an introduction, and two books of fourteen and twenty two chapters respectively.

This pamplet contains ariton's chief contribution to thought on the subject of divorce. In the first book is found the core of his whole argument. All else that he wrote on the subject either reinforced, amplified, or recapitulated the arguments found here.

In the introduction to the treatise, addresed to parliament, Milton expounded hie critical attitude toward contemporary methods of thinking.

Who of all teachers and masters, that have ever taught, hath drawn the most disciples after him, both in religion and in manners, it might bo not untruly anewered, custom. . - oustom countenances error; and these two between them would persecute and chase away all the truth and solid wisdom out of human $11 f e .1$

1. Mlton, op. c1t., p. 573. 
He admonished them that "honest liberty is the greatest foe of dishonest $1100 n s e, "$ and that "it was erroneous to believe the contrary."I He sald that euperstition cansed the greatest burden in the world.

The superstition of the papist is, "Touch not, taste not," when God bids both; and ours 1s, "part not, Beparate not," when God and charity both permits and commands.2

Fngland, Milton felt, hed had the honor vouchsafed from heaven to bring reformation to the world, and had proved it in the past.

Let not England forget her precedence of teaching nations how to live... Knot and exerciso the privilege of your honored country... this glorious 3 act will style you the defenders of charity. ${ }^{3}$

In attempting this act of reformation, Milton mode clear that he brought true enlightenment, free Irom superstition and error.

I seok not to seduce the simple and illiterate; my errand is to find out the choicest and learnedest, who have the high gift of wisdom to answer solidis
or to be convinoed. . .

The first book lays down his thesis, supports it, and onforces it. In the preface Milton pointed out that most of man's miseries are self mado and self inflioted

\footnotetext{
1. Ib1d., p. 574.

2. IbIa., p. 575 .

3. IbId., p. $57 \%$.

4. \$00. o1t.
} 
depending on his wrong interpretation of God's laws. For many ages marriage itself lay in disgraco as a work of the flesh; then it was thought sacramental, indisso1uble. Milton asked for one forward step, legalization and acceptance of divorce, to be taken; not to contribute to licentiousness, but as necessary to man's happiness.

Not that licence, and levity, and unconsented breach of faith should herein be countenanced, but that some conscionable and tender pity might be had of those who have unwarily, in a thing they never practised before, made themselves the bondmen of a luckless and holploss matrimony. 1

The thesis is formalated thus:

That indisposition, unfitness, or contrariety of mind, arising from a cause in natare unchangeablo, hindering, and ever likely to hinder the main benefits of conjugal society, which are solace and peace; It is a greater reason of divorce than natural frigidity, especially if there be no children, and that there be mutual consent2 (Chapter I).

The nine arguments supporting this the sis follow three general I1nes:

1) It is irrational not to belleve that the prinoiple of any law is not to be an end in itself but to serve an end. The ond of the divorce law must be the same as the end of the law on marriage (Chapters IIIX).

I. IbId., p. 579.

2. Ib10., p. 580 . 
2) Divorce cannot be against the ends of the lawe of nature, canon or human law, or divine law (Chapters $X-X I I I$ ).

3) Enforcement: restraint of lawful liberty may result in fanaticism or false doctrine (Chapter XIV). The first argument is that no contract is binding which is irrational, contrary to its own purpose and the partiea who make it (Chapter II). "No Corenant whatsoever obliges against the main End both of itgelf and the perties covenanting."I since it was not good for man to be alone, God made a help meet for him. Whon the wife is no help meet, she is no wife.

- - if a women be naturally so of disposition, as will not help to remove, but help to incresse that same Godforbidden Ioneliness . . such a marriage can be no marriage...2

There is 1gnorance in the canon law which protides for the right of the body in marriage and nothing for the wrong of the mind (Chapter III).

- - Por if it happen that nature hath stopped or extinguished the voing of sensuality that marriage is annulied. But though all the facultios of underatanding . . appear to be so 111 and so aversely met . . 28 that noither peace nor any sootable contentment can follow ... the contract [in canof law] shall stand as firm as evor, botide what will.3

I. Ibid., p. 581.

2. Ibid., p. 582 .

3. $\underline{\text { too. o1t. }}$ 
Applying to Milton's own experience is his

statement that despite "all the wariness that can be used, it may befall a discreot man to be mistaken in his choice, $n^{l}$ bocause:

- a sober men honoring the appearance of modesty . - may easily chance to meet, if not with a body impenetrable, jet with a mind to all other due conversation inacoessible, and to all the more estimable and superior purposes of matrimony useless and almost lifeless . . 2

The second argument is: "... the reasons which now move him [man] to dirorce are equal to the best of those could first warrant him to marry. ..." 3 Milton considered it a "violent and cruel thing to force the continuing together of those whom God and Nature in the gentlest ond of marriage never jolned." 4 Three evils result; 1) ". . the imputation is f1xed upon God... of conniring and disponsing with open and common adultery .. " ${ }^{5}$, 2) the law and gospel are made open to contradiction, 3) the suprome dictate of charity is neglected and violated (Chapter IV).

The third argument discloses lilton's belief that without a dirorce law ". . he who has happened

1. IbIa., p. 583 .

2. L0c. cit. CI. post, p.110.

3. HIIton, op. e1t., p. 584.

4. Ioc. dit.

5. IbId. . p. 583 . 
where he finds nothing but remediless offences and discontents, is in more and greater temptations than ever before"l (Chapter V). - . when he shall find himself bound fast to an uncomplying discord of nature, or, as it oft happens, to an 1mage of earth and phlegm, with whom he looked to be the copartner of a sweet and gladsome society,. - . though he be almost the strongost Christian, he will be ready to despair in virtue, and muting against Divine Providence...2

Milton, in his fourth statement in defense of his thesis, believed that marriage is a covenant founded upon lore and peece.

- God regard Love and Peace in the Family more then a compulsive Performance of Marriage, which is more broke by a grierous continuance, than by a noodful Divorce . . Marriage . . consists... In unfelgned love and peace, and . - where love cannot be, there can be left of wedlock nothing but the ompty husk of an outside matrimony as undelightful and unplessing to God as any other kind of hypocrisy.3

When such a situation exists, it is better to break the marriage where no covenant of love and peace exists and to separate rather than to ruin it with discord (Chapter VI).

and it if logs a breach of wedlock to part with wise and quiet consent betimes, than atill to soll and profane that mystery of joy and union with 8 polluting sadness and perpetuel distemper ...4

1. Ibid., p. 586 .

2. Lac. cit. CI. pogt, p. 109. CI. ante, p. 39 .

3. IIItion, op. cit., p. 585.

4. Ibid., p. 586 . 
The fifth argument supports a Chriation 11 fe. Milton thought,". - there is no christion duty that is not to be sersoned and sot off with cheorfulness... nothing more than disturbance of mind suspends us from approaching God..." This kind of marriage has tho same effect on Christion as an idolatrous match (Chaptor VII).

During Biblical times the question of marriage with herotica was important. Since God commandod Abraham to send away his irreligious wife, and st. paul asked, What part hath he that believeth with on infidel?"2 Milton answered: (Chapter VIII)

Where there is no hope of converting, there always ought to be certain religious adversation and abhorring which can in no way ort with marriage . . a right believer ought to divorce an idolatrous heretic unless upon better hopes those mon ought to soparate.3. but hates to join, Adultery 18 not the grestest breach of matrimony; there may be other violationa as great. The ohief ends of matrimony include godly society and civil onds es well as the marriage bed (Chapter IX).

The second general line of arguments, that dirorce is against the laws of nature, canon or human

1. Loc. cit.

2. IbId. . 588 .

3. Ib1d., p. 589. Cf. post, pp. 74, 100. 
law, and divine law, is next presented.

That to forbid divorco sought for natural

causes is against Nature is the basis for the sixth argument. This is one of Milton's most fundamental and important points. In fact, this argument from nature is found throughout his other reasons for dirorce (Chapter $X$ ). ${ }^{I}$

- . it is tho most injurious ond unnatural tribute that can be extorted from a person endued with reason, to be made pay out the best substance of his body, and his soul too, es some think, when either for just and powerful causes he cannot like, and from unequal causes finds not recomponse. ${ }^{2}$

In stirring pasages Milton calls it folly to combat invincible causes until the end of life. If disfigurement of body can destroy sympathy of mind, much more can annoyance of mind render invalid acts and faculties of the body. This is true according to the fundamental lawbook of nature.

The serenth defense relies on canon law - that if either party be found contriving against another's Iffe, they may be separated. Milton added to the interpretation of the law: (Chapter XI)

- a sin against the life of marriage is greater than a sin against the bed... When therefore this denger is foreseen, that the

I. Cf. post, p. 105.

2. Milton, op. cit., p. 591 . 
Iife is in peril by 11ving together, what matter is it whether helpless grief or wilful practioe be the cause? 1

If evergone who marries has not the calling for 1t, when unfitness is found force should not be used to continue the marriage, is Milton's eighth argument for divorce (Chapter XII).

The ninth and final argument is that marriage is more than human (Chapter XIII).

- - the chief society thereof to bo in the soul rether than in the body, and the greatest breach thereof to be unfitness of mind rather than defect
of body. ${ }^{2}$.

Marriage 18 compared with all the other covenants warrantably broken for the good of man. God would not set the ordinance above the man for whom it was ordained. Marriage was made for man, not man for marriage.

The argument is enforced in a final chapter, where Milton advanced the theory that perhap fanatics in religion were forced into false doctrines by the restraint of some lawful liberty. 3 Perhaps also, he thought, that because of these purposeful restraints, the church was held in derision by some. Forbidaing to divorce is as cruel as forbiding to marry (Chapter XIV).

1. Ibid., p. 592. CI. post, p. 104 .

2. IIIton, op. cit., p. 593.

3. Cf. post, p. 109 . 
Book Two of the Doctrine and Discipline of Divorce consists in part of the defienses of the foregoing argumente. Milton antioipated the theological and scriptaral objections on one hand, and on the other advanced both his om ideas as to the correct interpretation of the two scriptural pessages referring to dirorce, and a program for handing divorce, founded on Biblical law and reason. Accordingly the first part of the book is negative in character, and the latter part, positive.

This second book sets a pattern that Milton followed in his later divorce writings. He real izod that a storm of disapproral would break over hia head; therefore he marshallod what authority was at hand, and with it and his now interpretation of pertinent scripture, tried to anticipate the attacks that were sure to follow. The organization, therefore, follows the argument that he foresaw and answered.

The chief argument againgt dirorce was that it was merely allowed the Jews for hardness of heart as a dispensation (Chapters II-VII). Som theologiano admitted the law of Moses as functioning in ancient times for Jews, but claimod it did not affect Christians:

(I) because it was no lew but merely the forerunner of a law to follow, (2) because it was permitted only and 
not approved, and (3) because it was merely a judicial law (Chapters VIII-XIII). Beza believed that divorce was againgt the law of God, and Milton specifically answered his argumen ts (Chapters XIV-XV).

For positive argument, Milton gave new interpretation of Christ's statements concerning divorce (Chapters XVI-XX). A divorce program end the book (Chapters XXI-XXII).

Milton compared first the ordinances of the sabbath and marriage and said, "If the sabbath was mado for man, and not man for the sabbath, 1 that marriage was even more made for the good of man. He believed that Christ did not mean to be taken word for word, but intended to administer one excess against the other (Chapter I).

The theologians! argument, that divorce was permitted to the Jews for hardness of heart, Milton contradicted by saying that the law cannot commit evil in the hope of doing some uncertein good (Chapter II). He amplified this argument: "That to allow Sin by Law is against the Nature of Low, the find of the Lawgiver, and the Good of the People."2 It is Impossible, thereiore, in the law of God, for it makes God the author of sin

I. Milton, op. cit., p. 595.

2. Ibid., p. $59 \%$. 
more than anjthing objected by the Jesults or Arminians against Prodestination (Chapter III).

Milton contested the thoologians' standpoint that dirorce is a dispensation for hardness of heart. He declared that it would do a sinner no good if the oracle of divine law provided for the impunity ond conventence of sin. Rivetus argued that God dispensed in an unknown way, which Milton beliered to bo an unsatisfactory answer to a Christian (Chapter IV). He defined a dispensation as improperly callod a "particular and exceptive law, absolving and disobliging from a more general commend for some just and reasonable cause."1 Properly he believed it to bo "some particular acoident rarely happening, and therefore not specified in the $18 \mathrm{w}$, but left to the decision of charity..." 2 (Chapter V). Milton granted that if a sin may be dispensed, that the Jew had no more right to be dispensed with than the Christian. He stated that "the Jew was bound as strictly to the performence of every duty as was possible; and therefore could not be dispensed with more than the Christian, and perhaps not as much" ${ }^{3}$ (Chapter VI). Howover the gospel is more charitable than the law and bears

1. Ib1d., p. 602.

2. Loc. cit. CI. pOSt, p. 101 .

3. LOC. CIt. 
with weakest infirmity (Chapter VII).

On the subject of Scripture, Milton explained Moses's Iaw:

- - when a man hath married a wife, if it come to pas8, that he cannot love her by reason of some displeasing natural quality or unfifness in her, let him write her a bill of divorce.l

Here liliton argued that this good and necessary law had been taken advantage of. He belioved that Christ'a answer to the Pharisees was to tell them what Moses was forced to suffer by their abuse of his law (Chapter VIII).

In the analysis given to the theologians' arguments against divorce in the interpretation of the scriptures, the command, "Therefore shall a man cleave to his wife and they shall be one flesh, ${ }^{2}$ is traced to its original idea. The primitive reason for never divorcing was God's promise to make a help meet for man; but she who is no help meet is no wife. Milton contended that marriage, "unless it mean a fit and tolerable marriage, is not inseparable neither by nature nor institution. " 3 He called those men perverse who call the law of Moses to be the law of the Lord, and evade the law of divorce (Chapter IX).

1. Ibid., p. 605.

2. IbIa., p. 606 .

3. Loc. cit. 
It is a vain argument to say that the law of Moses is no law but the promise of another law to follow (Chapter $X$ ), and it is wrong to say dirorce was permitted by law but not approved. Milton gave many classical examples of actions against approval. D1sapproval did not redeem Pilate. ${ }^{1}$ What then of Moses? He concluded:

- . In such an accident it will best behoore our soberness to follow rather what moral sinai prescribes equal to our strength, than fondly to think within our strength all that lost paradise relates 2 (Chapter XI).

Milton refuted also a third theological argument, that the law of Moses was a judielal law and so was abrogated. Milton contended it was a law of moral equity, and that Christ disputed merely the morality of the law (Chapter XII). He quoted the theologian Perking ${ }^{3}$ to prove that in Matthew Christ does not confute Moses's law "but the false glosses that depraved the law; .. so that by his own inference, Christ did not absolutely intend to restrain all divorces to the only cause of adultery.n4 That dirorce was allowed only because it was an old Egyptian custom, Milton dismissed as absurd. He insisted that Moses gavo his law willingly (Chapter XIII).

I. CI. post, p. 102.

2. Miton, op. cit., p. 609 .

3. Supra, p. 26 .

4. Miton, op. cit., p. 610 . 
Beza belleved that a politic law could regulate sin. Milton answered, "To make a regularity oi gin by law, either the law must straighten sin into no sin, or sin must orook the law into no law"I (Chepter IV). Beza also contended that dirorce. was granted not for men but for afflicted wires. Mlton used Biblical references to prove man's superiority over woman.2 Continuing the discussion of Christ and the Pharisees, Milton believed that:

And since they [the Pharisees] had taken a liberty which the law gave not, he amuses and repels their tempting pride with a perfection of paradise, which the law required not ...3 (Chapter XV)

Next Milton undertook to clarify the Biblical statements which so conflict with the idea of divorce. "They must be one flesh" and "Those whom God hath joined together, let not man put asunder"4 are explained by Milton in the light of compatibility of mind rather than carnal joining of flesh (Chapter XVI).

The statement of Christ, "Whosoever shall put away his wife, except it be for fornication, and shall marry another, committeth adultery, "5 was explained by Grotius as naming adultery rather as one example of

I. Ibid., p. 6II.

2. CI. post, p. 114 .

3. Milton, op. c1t., p. 613.

4. Loc. cit.

5. IbId. . 614 . 
other like cases. Milton agreed with him that the use of the word fornication signifies matrimonial transgression other than adultery (Chapter XVIII). Ho argued too: I) that an ancienter law is to part where one cannot love, 2) that the gospel enjoins no new morality, and 3) that Christ's statement is no command of perfection further than it partakes of charity (Chapter XVII). Milton also explained Christ's manner of teaching in which the student must compare his words with other precepts to get at the truth. In the same way one must interpret the words of St. Paul, "God hath called us to peace, ${ }^{n}$ as applying not only to an adulterous marriage, but to all kinds whon Christian liberty and peace are obstructed (Chapter XIX).

Charity is given with all commandments. Since neither reason nor scripture laid the unjust austerity upon divorce, it is due merely to letter bound servility of "canon-doctors." Milton scorned the papists for being the strictest forbidders of divorce and violating wodlock most (Chepter XX).

The program for handing divorce is next set forth. Since, Milton thought, it is a matter of conscience, it should not be tried by law as the papists

1. IbId., p. 6I8.

2. C1. post, p. 111 . 
hare done. Only differences about dowries, jointures, and the punishing of adultery should be referred to the magistrate who exists to secure peaceable living in the commonwealth. The law can to no rational purpose forb1d divoroe; it can only take care that the conditions of dirorce are not infurious to either party (Chapter $\operatorname{XXI)}$.

Milton referred the reader to Selden's Lat of Nature and of Nations to continue the argument that dirorce should not be restrained by 1 aw.

An apostrophe to parliament sumb up the arguments of the preceding chapters. Milton urged the power returned to the masters of the families who, before minister and elders, should be able to proclaim a bill of divorce. The experience of the Jews had proved it a workeble plan.

They shall vindicate the misreputed honor of God - - recover the misattended words of Christ... set free many daughters of Israel . . restore to [man] his just dignity and prerogative in naturo - and marxiage they shail reduce to a more certain haven and retirement of happy society ... The vigor of discipline they may then turn with better suocess upon the prostitute looseness of the times... (Chapter XXII)

II. JUDGMENT OF MARTIN BUCER (1644)

The occasion of the publication of the Judgment

1. MIIton, op. c1t., pp. 625-626. 
of Martin Bucer has boen explained.1 It was intended as a confirmation and justification of the Doctrine and Disolpline of Divorce. As Milton himself pointed out, 2 he was ignorant, in his first divorce tract, of De Regno Christ1, but once discovered, he put it to immodiate use. The denunciation which he received after the publication of the first dirorce tract made doubly welcome the discovery of an eminent churchman who held the same views on divorce. Milton therefore hastened to address to parliament this second dirorce tract which contains, beside the introduction, testimonials to Bucer, selected chapters from Bucer's book summarized by Milton, and a postcript also addressed to parliament.

Milton first identifled his authority with a long list of testimonials from prominent Reformers as to Bucor's worth and genius. A catalog is sufficient here: Grinoous, Calvin, sir John Cheok, John Sturnius, Beza, Fox, Dr. Pern, Acworth, Verheiden, and Peter Martyr. In the introduction and postscript Milton summarized both his own position and Bucer's on the subject of divorce. He insisted that his own name should no longer be in disrepute because of the learned author1ties who supported his theories, and again admonishod 
Parliament not to lose its liberty but to learn the truth.

Bucer, in De Regno Christi, his last book to Edward VI, urged the discipline of reform in the land. In the first place, order in the kingdom presupposes order in the family. Secondly, a direct analogy of sense, reason, law, and gospel should be used to understand the diroree situation clearly. Iastly, Bucer considered the point of divorcement a prime part of discipline in church government.

Milton, in explanation of his own position, declared he was but an instrument in the hand of God because his first writing was entirely without authority, and only since the Doctrine and Discipline of Divorce had he found the authority of Fagius and Bucer justifying his arguments. He criticized his opponents who from afar disputed his theories without coming to him for further explanation.

The body of the pamphlet is a summary of Chapters 15-47 of De Regno Christi. Since Bucer's form of argument does not always parallel Milton's, I have broken the sequence of chapters in order to present more clearly Milton's choice of supporting arguments. Bucor definitely agreed with Milton's original 
thesis - (Doctrine and Discipline of Divorce, Book I, Chapter I)..$^{1}$ According to him a promise of marriage should be revokable becanse there is no true marriage between those who do not agree in true consent of mind (Chapter 19). The properties of a true marriage are: 1) that they should Iive together, 2) that they should love one another, 3) that the husband should bear himself as the head and preserver of his wife, and 4) that they befraud not each other of conjugal benevolenoe (Chapter 39). Non-fulfillment of those conditions should dissolve matrimony. It is wrong for a man and wife to bear one another's cross because true charity - - prefers public honesty before private interest, and had rather the remedies of wholesale punishment appointed by God should be in use than by remissness the licence of evil doing should increase.2

Christian emperors approved of divorce by mutual consent (Chapter 40).

Most of the selected chapters from the Judgment of Martin Bucer reinforce the arguments against the theologians in the second book of the Doctrine and Discipline of Divorce. A digest of Chapters 25-30, 38 , and 43 shows that Bucer agreed with Milton on the matter of interpreting the scriptare (Doctrine and Discipline

1. Supre, p. 56 .

2. M11ton, op. c1t., p. 644. 
of Divoroe, Book II, Chapters VIII-IX). Ho thought that Christ came to fulfil the law of God and therefore could not condemn what God once commanded (Chapter 25). God commanded divorce where true conjugal love did not exist (Chapter 26). The samo law applies to Christians and Jers (Chapter 27). Christ did not intend to make any new laws (Chapter 28). It is wicked to strain the words of Christ beyond their true purpose (Chapter 29). The Bible contains many seeming contradictions, and only through prayer and an open heart can the words of christ be interpreted (Chapter 30).

The nature of holy wedlock is determined, and if only one be wanting in either perty, the covenant which God instituted and called marriage doos not hold between them. There lies the interpretation of christ's worda, "Those whom God hath joined, let no man separate"1 (Chapter 38).

The words of Christ which seem not to allow divorce except for adultery depend on the Pharisees' question which was "whether it were lawful to put away a wife, as was truly, and according to God's law, to be counted a wifen2 (Chapter 43 ).

I. IbId., p. 642. Supra, p. 60 . Poat, p. 100.

2. Milton, op. cit., p. 645 . 
Chapters $35,36,41$, and 42 from De Regno

Christ1 continue the support of Milton's arguments on the clarfication of scripture (Doctrine and Discipline of Divorce, Chapters XVII-XIX). Paul's seoming contradictions are explained in this light:

- Whatever exception may be proved out of God's law, be not excluded from those places. For the Spirit of God doth not condem things formerly granted and allowed, where there is like cause and reason (Chepter 35 ).

In I Cor. Vif is found precedent for granting divorce for desertion. Therefore it cannot be that divorce oan be granted for fornication only.

God . . hath provided for innocent and honest persons wedded, how they might free themselves by lawful mean of divorce, from the bondage and iniquity of those who are falsely termed their husbands or wives2 (Chapter 36 ).

Therefore desertion, impotence, leprosy, and madness are also just causes for dirorce (Chapters 41, 42). Milton's program for the granting of divorces was partly anticipated by Bucer (Doctrine and Discipline of Divorce, Book II, Chapter XXI). Bucer said that marriage is a civil thing, and only by fraudulent persuasion and force did the popes take the power in their own hands (Chapter 15). The laws of God, rather than those of man, should be followed (Chapter 17). Holy wedlock should be

1. Ibid., p. 641.

2. Loc. cit. 
kept pure, and offenders punishod by the magistrates (Chapter 21).

A woak point in the Dootrine and Dibcipline of Divorce, aupport of the divorce program through experience, gained considerable reinforcement from $\underline{D}_{\theta}$ Regno Christ1. Milton had previously used only the experience of the Jews as precedent (Doctrine and Discipline of Divorce, Book II, Chapter XXII). Bucer pointed out that early Christian emperors granted dirorces with remarriage permitted (Chapter 22), and thet many early Christians were divorced and remarried (Chapter 24). Although married priests used to be removed from office, their marriage was not dissolved, nor were they excommunicated (Chapter 23).

The conclusions of Bucer'g erguments reaffirm the points that chastity and pureness of life cannot be restored unless it first be established in the homes, and that wise princes ought:

- . to punish with severity whoredom and adultery; next to see that marriages be lawfully contractod, and in the Iord; then, that they be faithfully kept; and lastly, that when unhappiness urges, that they be lawfuliy dissolved, and other marriages granted, according to the law of God, and of nature, and as the constitutions of plous princes have decreod. . I (Chapter 47). 
III. TETRACHORDON (1645)

Milton did not rely solely on the Judgment of Martin Bucer to strengthen his position. Since the attack by Palmer in Parliament had been delivered after the Bucer tract, 1 he must have thought ho neoded moro outhority to support his thesis. The most impressive support he could gain was that of the Bible. Aocordingly a detailed study of the scripture, not only of those passages previously examined, but also of additional related verses, resulted in Tetrachordon. 2 Its chlef purpose to to rationalize seemingly conflicting Biblical texts; and although it added nothing new in the way of argument, it contributed much in the field of contemporary scholarly prestige.

Totrachordon is an exposition of the four chief places in the scriptures which treat of marriage, or nullities in marriage, and is the longest of the divorce tracts. It resembles most the second book of the Doctrine and Discipline of Divorce. The conclusion states a solem warning of the resulte that will follow if his advice on dirorce is not heeded. The body of the pamphlet, Tetrachordon, is

1. Supre, p. 45 . 2. IOC. cit. 
divided into a verse by verse anelysis of the four chief scriptural paseages referring to marriage or divorce: Gen. 1:27,28 compared and explained by Gen. 11: 18,23,24; Deut. 24:1,2; Matt. 5:31,32 with Matt. 19:3-11; and I Cor. 7:10-16. These are followed by more theological sanction from early authorities and primitive christian laws, and legislative sanction by the intended act of Parliament during the reign of Edwsrd VI. I shall follow the verse by verse plan of Milton in my summary.

Gen. 1:27. So God created man in his own image, in the image of God created he him; male and female created he them.

Milton argued that since man was made in the Image of God, he should not become the thrall of women whose "wilfulness or inebility to be a wife frustrates the occasional end of her creation..." Nor is woman bound to be "the vassal of him who is the bondslave of Satan: she now being neither the 1mage nor the glory of such a person ... ${ }^{2}$

Gen. 1:28. And God blessed them, and God said unto them, $\mathrm{Be}$ ye fruitful and multiply, and replenish the earth...

Barrenness can be a legitimate cause of divorce.

Gen. 2:18. And the Lord said, It is not good that man should be alone; I will make a help meet for him.

1. MIton, op $\frac{\text { cIt. }}{\mathrm{p} \cdot 643 \text {. }}$
2. Ibid., p. 654. 
These verses in the second chapter of Genesis are considered a commentary and elaboration on the first chapter. Milton felt that God ordained marriage to be indissoluble in love and helpfulness, and that our presumption had changed the state and condition of the ordinance. Previous to the creation of woman Adam was not entirely alone; he had the compeny of the angels and God, so alone meant "alone without woman." Milton asked:

Why should God mock us, by forcing that upon us as the remedy of solitude, which wraps us in $a$ misery worse than any wilderness . . I

Such a marriage is not God's institution, and therefore no marriage. To put fleshly appetite before reason is to turn nature upside down.

Gen. 2:23. And Adam said, This is now bone of my bones and flesh of my flesh; she shall be called Woman because she was taken out of man.

Adam spoke of the "shell and rind" of matrimony, but God spoke of "love, and solace, and meet help, the soul both ot Adam's words and matrimony. "n

Gen. 2:24. Therefore shall a men leave his father and his mother, and shall cleave unto his wife; and they shall be one flesh.

Milton felt that "therefore" is the important word here. A man shall leave his home only if the inward I. IbIa., p. 657. 2. Ibid., p. 659 . 
essence of matrimony exists. Weaving a garment of dry sand would be as impossible as making "one flesh" of man and wife provided fitness of mind and disposition did not join them together. "One flesh" in itself puts man no higher than the beasts. Many authorities are examined to discover a theologians' definition of marriage. Milton offered this: "Marriage is a divino institution, joining man and woman in love fitly disposed to the helps and comforts of domestic life."l

Deut. 24:1,2. When a man hath taken a wife, and married her, and it come to pass that she find no favor in his eyes because he had found some uncleanness in her, then let him write her a bill of divorcement, and give it in her hand, and send her out of his house.

And when she is departed out of his house, she may go and be another man's wife.

Milton argued first that this is a law of God, quoting theological authorities to prove that end, and rodetined "uncleanness" as meaning the "nakedness of anything"2 applying equally to body or mind. Then, to vindicate this law from the calumn in which it was held, he adrocated twelve arguments supporting it. Briefly they are: 1) Nature dictates that if a man marries to find a help meet, what is more natural to dirorce if the wife is no help meet? 2) It is unjust to force a man into misery and discomfort. 3) All covenants are 
Intended for the good of both parties. 4) The law intends to see all covenants most faithfully performed. 5) The law 18 to tender the liberty and humen dignity of those who live under it. 6) God gave this law to men and women. 7) If a marriage can be dissolved by exterior powers (parents, masters, etc.) why may not the power of marriage dissolve itself? 8) The law distinguighes the privilege of an honest and blameless man from the punishment of a notorious offender. 9) Provided a man committed a rash act, he should not have to bear the fruits of his folly with the endurance of a whole life lost to all household comfort and society. Why should his own rash act bind him, rathor than the other's fraud acquit him? 10) Marriage is solemn and holy and should be performed sincerely. 11) A chief matrimonial end is the service of God, and unfit marriage unhallows a man. 12) All law should be arailable to some good end.

Milton asked who shall judge - the law of God and ancient Christians, or the illegitimate law of monis and canonists, the most unexperienced and incompetent judges of matrimony. I

After the elaboration of these twelve reasona, Milton next faced a common criticism of divorce, that it 1. Ib1d., p. 673. 
opened the door to license and confusion. He felt that It was better to relieve by law the just complaints of good men, than to curb the license of wicked men. As a final barb he added that if men persisted in calling God's law sinful, they had better look to it they did not open a worse door to blasphemy. He asked why not, if they are so anxious to forbid that which might cause trouble, do they not leave God's law alone and legislate for prohibition of liquor which causes both sin and suffering?

Matt. 5:31,32. It hath been said, Whosoever shall put away his wife, let him give her a bill of divorcement.

But I say unto you, That whosoever shall put away his wife, saving for the cause of fornication, causes her to comit adultery: and whosoever shall marry her that is divorcod, committeth adultery.

Milton protested that the law of Christ was charity, that christ did not mean to rebuke the law but the Pharisees' Interpretation of it. They broke the law in not marking the divine content, obeying only the lotter, and depraving the lotter with sophistical expositions.

Matt. 19:3. And the pharisees came unto him, tempting him, and saying unto him, Is it lawful for a man to put away his wife for every cause?

Milton here pointed out that the pharisees came to tempt, not to learn, and so deserved a strict answer. 1. Ibid., p. 674. 
He quoted old writers to show the political criticism into which they were trying to lead christ, the recent divorce of Herod, and showed how different translations change the connotation of "put away" and "for every cause" to a looser meaning showing the prevailing low ethics in divorce proceedings.

Matt. $19: 4,5$. And he answered and said unto them, Heve ye not read, that he which made them at the beglnning, made them male and female?

and said, For this cause sholl a man leave father and mother, and shall cleave to his wife, and they shall be one flesh.

Milton felt that Christ used this most vulgar, most animal and corporal argument with the phariseos as if in their licentious divorces they made no more of marriage.

Matt. 19:6. Wherefore they are no more twain, but one flesh. What therefore God hath joined together, let no man put asunder.

If marriage is unfit, is it God's joining? And if it is unlawful for a man to put asunder what God hath joined, Milton warned man not to join what God has put asunder.

Matt. 19:7,8. They say unto him, Why did Moses then command to give a writing of divorcement, and to put her away?

He saith unto them, Moses because of the hardness of your hearts suffered you to put away your wives; but from the beginning it was not so.

Milton here set forth first, that the common explanation of the pasage is untrue, and secondly, his 
own interpretation. In exposition of the lawfulness of this divorce decree of Moses, Milton used all the arguments of the Doctrine and Discipline of Divorce. He insisted on the rightness of the law because God's laws are perfect, that law cannot contradict itself, that God is the author of no sin, and that law establishes no license to sin; and again repeated that divorce is no dispensation. He pointed out that "ouffer" is a legal phrase of permission only. Hardness of heart is not a stubborn resolution to evil. If it is suffered in the best laws, why abolish it in this law? Onder it good men have the right to dirorce, bad men only the sufferance. As for "in the beginning it was not so," that is true. In the beginning man was perfect, and man and woman needed no dirorce. The most perfect action open to a man in a bad marriage is to divorce. The rule of perfection is now nearest the rule of charity.

Matt. 19:9. And I say unto you, Whoso shall put away his wife, except it be for fornication, and shall marry another, committeth adultery: and who marrieth her which is put away, doth commit adultery.

"I say unto you" was not to contradict the law of Moses. Christ did not come to rebuke or shame Moses or to put a burden upon men. "Whoso shall put away his wife" depends here upon the word wife, a comfortable help and society. Fornication has many meanings in the Bible and 
is a broader term than adultery. It signifies "constant alienation and disaffection of mind"l or the continued practice of disobedience and crossness from the duties of love and peace. Adultery was not necessary to mention because by law it was already punishable by death. "Whoso marries her that is put away" refers to collusion, then frequent among the Jews, of changing husbands and wives through inconstancy and unchaste desire. In all, Milton thought Christ meant by his speech:

- . first, to amuse his tempters, and admonish in general the abuses of that Mosaic law; next, to let Herod know a second knower of his unlawful act, though the Baptiat were beheaded; last, that his disciples and all good men might learn to expound him in this place, as in all his other precepts, not by the written letter, but by that unerring paraphrase of Christian love and charity, which is the sum of all commands, and the perfection. 2

Matt. 19:10. His disciples say unto him, If the case of a man be so with his wife, it is not good to marry.

In past conversations with his disciples, Christ did not explain his ldeas fully to them, but left them often in amazement. So in this case, he did not amplify his statements. That that was their reaction, Milton felt was perfectly natural since they had been bred in the pharisaean doctrine where a wife could be divorced for any cause.

1. Ibia., p. 692.

2. Ibia., p. 694. 
I cor. $7: 10-16$. And anto the married I command, yet not I but the Iord, let not the wife depart from her husband.

But and if she depart, let her remain unmarried, or be reconciled to her husband: and lot not the husband put away his wife.

But to the rest speak $I$, not the Lord: If any brother hath a wife that believeth not, and if she be pleased to dwell with him, let him not put her away.

And the woman which hath a husband that believeth not, and if he be pleased to dwell with her, let her not leave him.

For the unbelieving husband is sanctified by the wife, and the unbelieving wife is sanctified by the husband: else were your children unclean; but now they are holy.

But if the unbeliever depart, lot him depart. A brother or a sister is not under bondage in such cases: But God hath called us to peace.

For what knowest thou, 0 wife, whether thou shalt save thy husband? or how knowest thou, 0 man, whether thou shalt save thy wife?

Milton thought that the pagan-Christian argument had very little force in his own age as such, but that an interpretation of it was relevant to 17 th century Englishmen. An incompatible wife was at the same time comparable to the unbelieving or infidel wife of the Corinthians, and as likely destructire of Christianity. In the same way Catholics had provided for divorce through desertion, Tim. 1:8. "If any provide not for those of his own house, he hath denied the faith and is worse than an infidel." The catholic divines interpreted fillure to provide as desertion. - Milton added, "To free us from that which is evil by being distant, and not from that which is an inmate, and in the bosom evil, argues an 
Improvident and careless deliverer."l He argued that persecution from an unfit wife was worse than desertion. Here he ended his argument from the scriptures, fearing that to elaborate more he would seem, "not to teach, but to upbraid the dulness of an age." 2

The next division of Tetrachordon treats of the judgment of authorities in the treatment of these four scriptural passages. First is that of the primitive church in which liliton listed the testimony of early writers as to the correct interpretation of Christ's sayings. Milton admitted that testimony in logic is not necessary, but believed that some people were of the weaker sort who like to follow leaders. Therefore he quoted from Justin Wertyr, Tertullian, Origen, Lactantius, Basil, Epiphanius, Ambrose, Jerome, and Austin, all of whom countenenced divorce for more reasons than adultery, and who put a broad interpretation on the scriptures. The second set of authorities quoted was that referring to early civil law in which Theodosius and Valentinian both ordained divorce by mutual consent. Third, the Greek church and civil law both supported divorce for causes equal to adultery which are contrined in the word fornication. The closing chapter of Tetrachordon states that 1. Ibia., p. 701. 2. Ioc. cit. 
divorce even for adultery was abolished by papal canon law enoroaching wrongly on civil law. Since the Reformation, leading divines had advocated dirorce for causes equal to adultery. The Reformation authorities quoted fully to substantiate this point have all been mentioned before by Milton, chiefly in his introduction to the Judgment of Martin Bucer. ${ }^{1}$ The latter part of this pamphlet is a continuation of the same type of support from outside authority that Milton followed in the Bucer pamphlet.

\section{COIASTERION (1645)}

The last of the divorce pamphlets was Colasterion. In it wilton added no new argumente to the divorce question. Rather he restated his points made in the Doctrine and Discipline of Divorce against which the offending pamphlet had been written, summarized his opponent's objections, and blasted them with a withering scorn.

It was written without chapters, and the only internal divisions are the changings of subject. It contains diatribes against the licenser and the writer of the pamphlet, and the answering of each argument agalnst the Doctrine and Discipline of Divorce in order.

1. Supra, p. 71. 
Because this is the only instance of known orlticism of the divorce tract, I will repert the opposing arguments. 1) Scripture does not order divorce. 2) No divorce is possible where diversity of religion exists. 3) From Deut. 22 - "If a man hate his wife, and raise an ill report that he found her no virgin. . ho might not put her away." 4) One Christian ought to bear with the infirmities of another, but chiefly of his wife. 5) If the husband ought to love his wife, as christ does his church, then ought she not to be put away for contrariety of mind? 6) All Christ's statements in Matthew forbid divorce. 7) wan and wife are one flesh, therefore not separate. 8) I Cor. 7. "married have trouble in the flesh." 9) a husband must love his wife as himself; therefore he may not divorce for any disagreement no more than he may separate his soul from his body.

Many of these arguments are weak or obscure. Against them wilton brought the whole of his reasoning as expounded in his provious pamphlets in a stylo remarkable chlefly for its coarseness of language. One example should be enough to demonstrate his type of argument.

He passes to the third argument, like a boar in a vineyard, doing naught else, but still as he goes champing and chewing over what I could mean by this 
chimaera of a "fit conversing soul," notions and words never mede for those chops; but like a generous wine, only by overworking the settled mud of his fancy, to make him drunk, and disgorge his vileness the more openly. All persons of gentle breeding (I say "gentle" though this barrow grunt at the word) I know will epprehend, and be setisfied in what I spake, how unpleasing and discontenting the society of the body must needs be between those whose minds cannot bo sociable. But what should a man say more to a nout in this pickle? What language can be low and degenerate enough?l

V. THE CHRISTIAN DOCTRINE (1655-1660?)

- final summary of Milton's position on divorco is contained in the tenth chapter of The christian Doctrine. In this work, written in Milton's maturity. the basic arguments for divorce are stated briefly and dispassionately.

After a passage in which marriage was defined, Milton opened the divorce question with the statement that marriage was not indissoluble or indivisible; that if the essential form was dissolved, it followed that the marriage itself was virtually dissolved. He reexamined the Biblical statement, what God hath joined, let no man put asunder," and marshalled a vast array of arguments founded on Biblical quotation against the interpretation that divorce was allowed the Jews only for hardness of heart. He reafílmed his belief that 1. MIton, op. cit., p.72I. 
"From the beginning it was not so" applied to marriage in 1ts original perfect institution. Fornication w88 redeflned as meaning any unclean thing. His last words on the subject were almost identical with his first:

It is universally admitted that marriage may be lawfully dissolved, if the prime end and form of the institution be violated; which is generally alleged as the reason why christ allowed divorce in cases of adultery only. But the prime end and form of marriage, as almost all acknowledge, is not the nuptial bed, but conjugel love, and mutual assistance through Iife... I

\section{SUMMARY}

The foregoing five treatises constitute Milton's contribution to the problem of divorce. With the exception of The Chrietian Doctrine they were written in a short period of time, 1643-1645.

The Doctrine and Discipline of Divorce was written bocause an intellectual interest in the question was focussed on a personal problem. The first book contained all the essential points that liliton made about divorce. The second was the keynote of those that followed. Its content was the use of interpretations of the Bible, sanction from Reason and Nature and psychology, and quoting from authorities to reinforce his position.

In The Judgment of Hartin Bucer Milton made his 
greatest use of another's opinions; the introduction and postacript only are his own. His chief noed from Bucer was authority for his interpretation of scripture. Tetrachordon was the final effort to rationalize conflicting Biblical quotations. Criticism had been such that his whole thesis depended on the success of that undertaking.

The publication of Colasterion was the only occasion in which Milton specifically answered definite objections. In this case, too, the main cause of disagreement was the interpretation of the scripture with which he justified his premises.

The Christian Doctrine, written in maturity, was a reiteration of his earlier opinions with the chief emphasis again on interpretations of words and passages from the Bible.

The succession of pamphlets brings out an interesting observation on the progress of Milton's argument. Because of contemporary criticism, he was driven more and more from defending his position on the grounds of philosophy, using Reason and Nature as the most important sanctions, to the use of scripture.

An analysis of Milton's use of the Bible, Nature, and Reason as sanctions for divorce will form the next chapter. 
ANALYSIS OF MIITON'S METHOD OF REASONING

The procoding chapter contains a summery of Milton's thought on the divorce problem as show in his five treatises on the subject. In this chapter I will analyze his mothod of reasoning as demonstrated in the divorce tracts.

I mentioned in the summary of Chapter IV that Milton had used two sanotions to prove his arguments, phllosophy and the Bible. The philosophical sanctions included an appeal to Nature and Reason; the latter was used chiefly as a means of interpreting the Blble. A now sanction, common to modern thought but not to the 17th century, was dereloped in the Doctrine and Discipline of Dirorce, that of psychology. Although Milton was ignorant of the actual term, psychology, he used it as a basis for argument in decrying the plight of men chained to "mute and spiritless"l metes.

This chapter will be divided into four sections: 1) Milton's direct use of scripture. This is relatively unimportant because most of the points he set out to make could not be proved by a literal interpretation. 2) The appeal to Reason. The use of this sanction forms I. Cf. post, p. 108 . 
the backbone of the divorce arguments. Reason as a guide to the interpretation of the Bible is the usual form of its use by Milton. 3) The ganction of Nature. This is closely allied to the preceding method. "What nature expects of men as shown by the Bible" might be another title. 4) The nature of man. Milton's regard for the individual man made him anticipate modern thought in the psychological necossity of compatibility in marriage.

\section{MIITON'S DIRECT USE OF SCRIPTURE}

Milton was too strongly Calvinistic to depend to any great extent on a literal interpretation of the Bible. In several instances, however, the straight text served his purpose. There was the matter of an establishment of the relationship between the sexes. St. Paul believed in the superiority of man over woman, saying. "I suffer not woman to usurp authority over the man," and "The head of the woman is the man, he the image and glory of God, she the glory of man. - Wives, be subject to jour husbands as is fit in the Iord."l Milton ombellished these precepts:

Nevertheless man is not to hold hor as a servant but receives her into a part of that empire which 
God proclaims him to, though not equally, yet largely, as his own image and glory: for it is no small glory to him, that a creature so like him should be mado subject to him. I

Milton elso found many statements in the old Testament which supported the correctness of divorce when marriage was no longer companionable. In Deut. 24:1. there was: When a man hath taken a wife . . and... she find no fevor in his ejes. . let him write her a bill of divorcement." From Isalah Milton quoted, "Wherefore come out from among them and be ye separate, said the Lord; touch not the unclean thing and I 111 receive yo." St. Paul added to that, "What fellowship hath righteousness . ." In II Cor. 6. Paul also said, "Misgoke not together with infidels." All of the foregolng statements were, according to Milton, direct permissions of divorce.

The Now Testament seomingly contradicts the law of Moses. To prove that christ's statements did not affect the previous laws, MIton quoted Luke 16:17. "And it is easier for heaven and earth to pass, than one tittle of the law to fail." On that point Milton built his late arguments, that the law of Moses was both legitimate law, and one still effective for Christians.

I. Ibid.. p. 653 . 
II. THE APPEAI TO REASON

In Catholic scholasticism revelation and reason were equal. With the Renaissance there was a growing reliance on reason, even in interpreting scripture. By the 17 th century prominent Reformers, many quoted by Milton in the latter part of fetrachordon, had used reason and nature as a criterion of Biblical interpretation. Instead of a literal interpretation of the Bible and Christ's words, the highest knowledge was believed to be gained through an application of natural good and the light of reason to the scriptare. Milton was a proponent of that school.

- We are not to repose all upon the literal terme of so many words, many instances will teach ue: wherein wo may plainly discover how Christ meant not to be taken word for word, but like a wise physician, administering one excess against another to reduce us to a perfoct mean...1

Concerning previous interpretations of the Bible, he said, ". . our Saviour's words touching divorce are as it were congealed into a stony rigor . . "2 $^{2}$

In order to break this "stony rigor" Milton offered aree interpretation of the Bible, based upon a reasonable conception of man's dignity and duty toward God. The first step was the definition of man's status, taken literally

1. IbId., p. 596 .

2. IbIa., p. 579. 
from the Bible sinoe he agroed with it, that man was on earth for the glorification of God. That man might be happy and so fulfil his destiny, God, to remedy his loneliness, created woman. That women only could remedy this loneliness Milton believed because previonsly sdam had had the beasts, the angels, and God, none of which was completely satisfactory. This is the basis for one reason for divorce, that if a bad wife does not relieve that loneliness, man in all reason should be free. ${ }^{1}$

God's words in planning the creation of woman were, "I will make a help meet for him." Milton reasoned here that if a woman were no help meet, she did not meet the standard erected by God's words and wes therefore no wifo. In a later interpretation of the words of chriat, in watthow, in which the Pharisees were instructed as to diroroe, Milton believed that Christ, by opecifically saying "wife" meant it in the true sense of "help meet."

and it might be further added, that if the true definftion of wife were asked in good earnest, this clause of bolng a "moet help" would show itseif so necessary and so essential, in that demonstrative argument, that it might bo logically concluded: Therefore she who naturally and perpetually is no "meet help" can be no wife; which clearly tekes away the difficulty of dismissing such a one.2

Milton's freest interpretation of the scripture

1. Cf. supre, p. 5\%.

2. Miton, op. cit., p. 606 . 
and the words of Christ was in regard to the institution of marriage, ordained for the newly oreated Adam and Bve. He believed that all Christ said on the subject was meant to be interpreted by the law of Moses, rather than, as was previously supposed, the law was to be interpreted by Christ.

If we examine over all his sayings, we shall find him not so much interpreting the law wi th his words, as reforring his own words to be interpreted by the law, and oftener obscures his mind in short, and vehement, and compact sentences, to blind and puzzle them the more, who would not understend the law ... I

How can we then with safety thus dangerously confine the free simplicity of our seviour's meaning to that which merely amounts from so many letters, whons it can consist noither with his former and cautionary words, nor with other more pure and holy principles, nor finaly with a scope of charity, commanaing by h1s express commission in a higher strain? But all rather of necessity must be understood as only against the abuse of that wise and ingenuous liberty, which Moses gave, and to terrify a roving conscience from sinning under that pretext.2

With this view of the seemingly contradictory statements made by Christ to the law of Moses, Milton set out to examine the institution of matrimony chiefly in regard to its indissolubility. He first atated that marriage was made for man, not man for marriage, and that God hath "revealed, his gracious will not to set the ordinance above the man for whom it was ordained." 3

1. Ibia., p. 603 .

2. Ibid., p. 597 .

3. Ibid., p. 594. 
Marriage was made for man, and not for God.

What thing ever was more made for man alone, and lese for God than marriage? and shall we load it with a cruel and senseless bondage, utterly against both the good of man, and the glory of God?l

since marriage, therefore, was made for man, then the good of man should be its end, and any marriage conflicting with that end should be dissolved. But man's chief duty is to glorify God, and nothing more than disturbance of mind keeps us from approaching God: ". . such a disturbance, especially, as both assaults our faith and trust in God's providence, and ends. . only in bitterness and wrath." 2

When God spoke of "love and solece and meet help"3 he spoke of the soul of matrimony. Milton explained that "Therefore shall a man cleave to his wife" ${ }^{4}$ was no absoIute, command because of the inference "therefore." For, he said, "That this is 8 solid rule, that every command given with a reason, binds our obedience no othervise than that reason holds."5 It is only with "meet help" that there is a reason for a man to cleave to his wife.

Using these ideas from the old Nestament, that God ordained marriage to relieve man's loneliness and that a
1. Ibid., p. 595 .
2. Ibid., p. 587 .
3. Supre; p. 78 .
4. Miton, op. cit., p. 606 .
5. Ioc. cit. 
Wife was created as a help meot, Milton carried this conception of joining still further. He pointed out the dangers of a misinterpretation of God's purpose. Milton interpreted Christ's words which had been the chief stumbling block to divorce: "Whom God hath joined, let no man put asunder." Milton said, ".. for ourely what God Intended and promised, that only can be thought to bo his joining."

Neither can any man give account wherefore, if those whom God jolns, no man may separate, it should not follow, that whom he joins not, gut hates to join, those men ought to separate.2

The disciples, after Christ's conversation with the Pharisees, said, "If the case of a man be so with his wife, it is not good to marry." 3 If they had traly understood Christ, Milton thought their answer would have been different. He wrote an answer for the disciples which he thought Christ would have applauded.

Master, if thou moan to malke wedlock as Inseparable as it was from the beginning, let it be made also a fit soclety, as God meant it, which we shall soon understand it ought to be, if thou recite the whole reason of the law. 4

Thas Milton, through a free interpretation of God's intent in the institution of marriage, proved that Christ's atatements, regarded in the light of the original

1. Ib1d., p. 614.

2. Supre, pp. 60,74 .

3. Matthow $19: 10$.

4. Milton, op. cit., p. 607. 
perfection of marriage, were not contradictory. Since man was not jet perfect, the ldeal of marriage was not always possible, and charity should come to the rescue.

He next applied the light of reason to the authenticity and scope of Moses's laws. The fact that Chrlet did not come to abrogate the law of Moses, was proved by a direct statement of christ. How applicable the laws were to Christians, and how authentic they still were he took many pains to demonstrate. First, Moses's law was just that, law, It was called a law by Christ, Mark 10:5. "For the hardness of your heart he wrote you this precept." Not only that, but it was no dispensation because:

A dispensation most properly is some particular accident rarely happening, and therefore not specified in the law, but left to the decision of charity, even under the bondage of Jewish rites,

Since the aim of the law of dirorce was to protect the institution of marriage, and the institation of marriage wa founded on "fit solace and help," Milton argued, to prove that the dirorce law was authentic, that no law should defeat its own ends. Therefore if true marriage did not exist, then divorce should remedy the situation and dissolve the marriage.

1. Ib1a., p. 602. Supra, p. 65 . 
For all sense and equity reclaims, that any 1 aw or covenant, how solemn or strait soever, either between God and man, or man and man, though of God's foining, should bind against a prime and principal scope of its own institution, and of both or either party covenanting . : .1

Miton believed that the law was an ond in itself and not to regulate sin.

To make a regularity of sin by law, oither the law mat straighten sin into no sin, or sin must crook the law into no law. The judicial law can serve to no other end than to be the protector and champion of religion and honest civility, as is set down plainly, Rom. xill., and is but the arm of moral law, which oan be no more separate from justice, than justice from virtue.2

To continue the proof that the law was right in 1tself, and not merely allowed without approval by Moses, Milton used an analogous case, that of pilate ${ }^{3}$ who, although he did not approve what he allowed, has nevertheless been demned through all eternity.

Nor can God be made the author of ain. Milton, through a long process of reasoning, proved that God, since he permitted Moses's law, consented to it; and if the law were sinful or no law, then God became the an thor of sin, an impossible and blasphomous situation.

Yet silence in the law is consent, and consent is accessory - . How justly, then, might human law and philosophy rise up against the righteousness of Moses, if this be true which our vulgar divinity fathers upon him, yea, upon God himselt, not silently

I. UIton, op. cit., p. 581.

Supra, p. 57 .

2. Supra, p. 68 .

3. Supre, p. 67 . 
and only negatively to permit, but in his law to dirulge a wrtten and general privilege to commit and persist in unlawful dirorces on the one hand, with security and no 111 fame? For this is more than permitting and contriving, this is maintaining: this is warranting, this is protecting, yea, this is doing evil...1

Therefore the divorce law was authentic and an ond in itself, not a tool to regulate sin, nor merely allowed without approval, nor sinful since it was made by God through Moseg.

Milton often used related quotations from the Bible to prove his points. In one instance he cited the Incident of Abraham who was commanded by God to send away his irreliglous wife and her son for the offenses they gave in a pious family. He felt this was in support of divorce because". - What kind of matrimony cen that remain to be - - when their thoughts and spirits fly asunder as far as heaven from hell?"8 Christ's otatements "Cast not pearls before swine.. Let him be to thee as a heathen. - Shake the dust off thy feet," were all used by kilton to reinforce his dirorce arguments. 3 in Dout. 22 "Thou shalt not sow thy vinoyard with divers seeds, lest thou defile both. Thou shelt not plow with an ox and an ass together," Milton found justification for his objections to 111 mated marriages. 4

1. Miton, op. c1t., p. 599 .

2. Ib1d., $\mathrm{p} \cdot 588$.

3. Ibid., p. 590 .

4. Ibid., p. 591 . 
Another interesting example of Milton's reasoning by analogy can be found in his application of canon law to his own interpretation of marriage. This application was made possible by Milton's interpretation of the true end of marriage as "love and solece and meet help." on the existence of those qualities depended the true life of marriage which could be destroyed when they no longer existed.

The canon law and divines consent, that if either party be found contriving against another's life, they may be serered by dirorce: for sin against the Iife of marriage is greater than the sin against the bed.. When therefore this danger is foreseen, that the life is in danger by living together, what matter 1s it whether helpless grief or wilful practice be the cause? . . What is life without the vigor and spiritful exercise of life? ${ }^{1}$

Thus it can be aeen, that no matter what his source may be, Biblical or canon law, Milton continualiy came back to the interpretation by reason of marriage and its prime ends as it was found in acripture. In no case was he satisfied with a literal reading. only by the light of reason did he read into the spirit of Moses's Isws and Christ's precepts.

The importence of this method of ressoning and justification of doctrine grew as Milton's discussion of divorce was carried on. It was present in the second 
book of the Doctrine and Discipline of Dirorce, most of the borrowed arguments from the Judgment of Martin Bucer were in this field, and almost the whole of Tetrachordon illustrates Milton's use of a rationalized interpretation of the soripture to support his divorce theories.

\section{THE SANCTION OF RATURE}

Quite like the interpretation by reason, and of almost equal importance, was the interpretation of the ocriptures in line with what nature intended for man. Since man had fallen from his high state of his original perfection, his natural inclinations made necessary adaptations of God's original plan. Man's limitations had to be taken into consideration.

This theory is the connecting Iink between Milton's interpretation of the Bible in the light of reason concerning marriage and dirorce, and the actual application of that theory to the life of man. The latter will be discussed later in the section demonstrating the psychological approach to the problem.

Throughout the whole of Milton's divorce tracts runs this argument for ueing nature as a guide to the scripture. It is so general, and so interwoven with the argaments from reason, that it would be impossible to 
segregate all the examples. Since Hature, therefore is used in most of the arguments in other sections of this paper, only a few references will be quoted here, enough only to demonstrate this method of argument.

Milton believed that marriage could be separated naturally and that man was responsible only to God in his decision.

Marriage is not inseparable neither by nature nor by inatitution . . And what is against nature is against law. 1

[Divoroe] - . Is a pure moral economical law, too hastily imputed of tolerating sin; being rather so clear in nature and reason, that it was left to man's own arbitrement to be determined between God and his own consclence...2

Milton explained that he thought the nature of man should be considered in a marriage.

We know that the flesh can neither join nor keep together two bodies of itself; whet is it then must make them one flesh, but likeness, but fitness of mind and disposition, which may breed the spirit of concord and union between them? If that be not in the nature of either, and that there has been a remediless mistake, as vain we go about to compel them into one flesh, as if we undertook to weave a garment of ary and . . God commends not impossibilities; and all the ecclesissticel glue that liturgg or layman can compound, is not able to solder up two such incongrous natures into one flesh of a true and beseeming marriage. 3

In accordance with the idea of two natures being disposed to make a fit marriage, Milton thought the

1. Mliton, op. olt., p. 606 .

2. Ibia., p.610.

3. IbId., p. 661 . 
results of such a union would bo disastrous.

- . It is the most unjust and unnatural tribate that can be extorted from a person endued with reason, to be made pay out the best substance of his body, and of his soul too, as some think, when either for just and powerful causes he cannof like, or from unequal causes finds not recompense.

In fact, nature is a fundamental guide in the right actions of man, and at no time does God force us to act againat these principles.

- . the fundamental lawbook of nature, which Moses never thwarts but reverences; therefore ho commands us to force notheing againat sympathy or natural order...2

\section{NATURE OF MAN}

Milton had proved to his own satisfaction that it was neither reasonable nor natural for man to be alone. But he also thought that marriage was a civil state that could be terminated if the conditions were not satisfactory. Hence a man had the right to choose the best life for himself, that is, make his environment such that he could best lead a Christion life and fulfill his duty toward God. If this environment were not contributing to that end, it should be changed. There the personal element arose because each man knew the best wife for himself. Milton quoted Palua Emilius, a Roman,

T. IbIa., p. 591.

2. Ibid., p. 592 . 
who, when asked why he put away his wife for no visible cause, answered, holding out his foot, "This shoe is a neat shoo, a new shoe, and yot none of you know where it wrings me." In the same way Milton felt the individual man only could settle the question of whether or not his own marriage was good or bad.

Milton most nearly approached modern thought in his passages relating to the psychological effect of a bad wife on the life of a man. He felt that the essence of life could be ruined by an unfit marriage, and that through repressions and inhibitions caused by an unhappy domestic life, many fanatical thoughts were bred. ${ }^{2}$ It was in these passages, most often quoted, that the most inspired prose of the divorce tracts is found. In these selections he displayed a more personel viewpoint than in any other phase of his writings on the subject. Scholars have long believed that his own unfortunate experience was the reason for the heat and bitterness of his expression. 3 It would be better, however, to let Milton spealx for himself on the personal and psychological necessity for divorce.

Whereof who misses, by chancing on a mute and spiritless mate, remains more alone than betore, and

1. Ibid., p. 623.

2. Supra, p. 62 .

3. Supra, p. 29 . 
in a burning 1088 to be contained than that which is fleshly, and more to be considered; as being more deeply rooted in the faultiess innocence of nature.1

- . Then he shall find himself bound fast to an uncomplying discord of nature, or, as oft happens, to an Image of earth and phlegm, with whom ho looked to be the copartner of a sweet and gladsome society...2

- - nor live in any union or contentment all their days, yet they shall, so they be but found suitably weaponed to the least possibility of sensual enjoyment, be made, in spite of antipathy, to fadge together, and combine as they may to their unspoakable wearisomeness, and the despair of all sociablo delight. 3

- . the fit union of their souls may be such as may eren incorporate them to lore and amity: but that may nover be where no correspondence is of the mind; nay, instead of being one flesh, they will rather be two carcasses chained unnaturaliy together; or as it may happen, a living soul bound to a dead corpee. 4

- - for $1 f$ the noisomness or disfigurement of body can soon destroy the sympathy of mind to wedlock duties, much more will the annoyance and trouble of mind infuse itsolf into all the acts and faculties of the body, to render them invalid, unkindly, and oven unholy against the fundamental lawbook of neture. .5

The above passages demonstrate the burning pen with which Milton urged the supremacy of the satisfaction of the mind in marriage, and the "brutish and base condition to be one flesh, unless where nature can in some

1. MIITOn, op. eIt., p. 584.

2. Supre, pp. 39,59 .

3. Ifiton, op. oft., p. 578 .

4. Ibid., p. 613.

5. Ibid., p. 592 . 
measure fix a unity of disposition." ${ }^{l}$ This unity of disposition was the most necessary part of marriage. This is why Milton's original thesis on divorce was formulated on the theory of incompatibility as a ground for divoree: ". . that indisposition, unfitness, or contrariety of mind. - is a greater reason of divorce than natural frigiaity." 2

Nor was a marriage without this unity of mind intended to be a trial of Christian patience as the papisto interpreted it.

- and make men day laborers of their own afflictions, as if there were such a scarcity of miseries from abroad that wo should be made to melt our cholcest home blessings, and coin them into crosses, for want whereby to hold commerce with patience. 3

That a sober man did not have the experience quite often to judge infallibly on the qualification of a wife, Milton felt was a common misfortune.

Whenas the sober man honoring the appearance of modesty, and hoping well of every social virtue under that veil, may easily chance to meet, if not with a body impenetrable, jet often with a mind to all other due conversation inaccessible, and to all the more estimable and superior purposes of matrimony useless and almost lifeless; and what a solace, what a fit help such a consort would be through the whole life of a man, is less pain to conjecture than to have experience.4

1. Ib1a., p. 613 .

2. Supra, p. 56.

3. Mition, op. oit., p. 620 .

4. Supra, p. 58 . 
In regard to the theory of the untholesome effect of inhibitions and repressions on men's lives, Milton anticipated modern psychology. He believed that perhap some of the fanatic sects were supported by men who through restraint and repression hed been turned from a normal and natural viewpoint toward life and God. He also thought that some mon did not support reform policies because they thought that were adultery baniohed, With divorce impossible, marriage would be too great a prison.

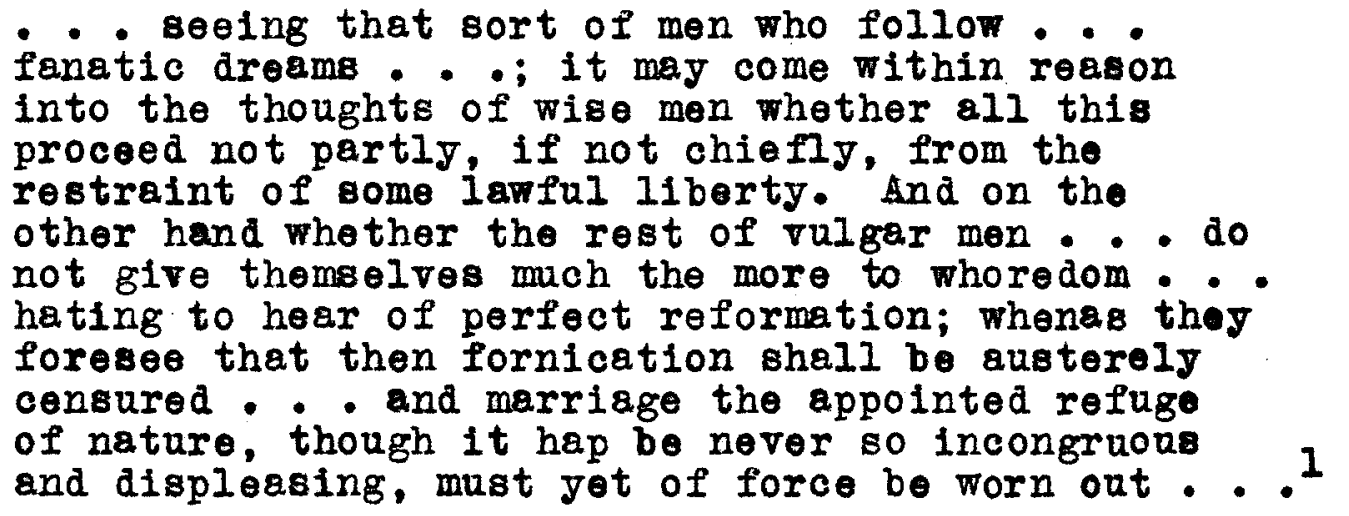
The solution of this whole problem MAlton beliered was to be found in the mossage of the gospel: charity. "Dirorce is not a matter of law, but of charity." 2 The precepts of God, the laws of Moses, all not to be interpreted as binding to man, but to be regarded in the light brought by chriat. It is on that point that ho

1. Supra, p. 69. 2. Milton, op. cit., p. 621 . 
rested his case having proved by arguing from Resson

and Nature based on the Bible and the nature of man

that divorce because of incompatibility was both

necessary and right.

Now if it bo plain that a Christian may bo brought into unworthy bondage, and his religious peace not only interrupted now and then, but perpetually and finelly hindered in wedlock, by misyoking with a diversity of nature as well of religion... whenever Christian liberty and peace are without fault equally obstructed: that the ordinane $\theta$ that God gave our comfort may not bo pinned to us to our undeserved thraldom, to be cooped up, as it were, in mockery of wedlock, to a perpetual loneliness and discontent, if nothing worse ensue. There be naught else of marriage between such but a displeasing and forcod remedy against the sting of brute desire; which fleshly accustoming without the soul's union and commixture of high intellect, as it is rather a solling than a fulfilling of marriage rights, so it is enough to embase the mettle of a generous spirit, and sinks him to a low and vulgar pitch of endeavor in $a l l$ his actions; or, which is worse, leaves him in a despairing plight of abject and hardened thoughts: which condition rather than a good man should fall into, a man useful in the service of God and mankind, Christ himself hath taught us to dispense with the most sacred ordinance of his worship, even for a bodily healing to dispense with that holy and speculative rest of sabbath, much more than with the erroneous observance of an ill-knotted marriage, for the sustaining of an overcharged faith and perseverance... To conclude, as without charity God hath given no commandment, so without it neither can men rightly believe any commandment given. 1

1. Ib1a., pp. 618-619. 
CHAPTER VI

CONCLUSIONS

In the history of social thought there have been three conceptions of man's responsibility that have roughly paralleled the Catholic and Protestant religions and modern social thought. The first concepttion that man was bound by tradition and form. With the Reformation came the 1dea of individual freodom and man's responsibility toward God through his own consclence. It was a period of emphasis on the value of the individual conscience in determining right and wrong rather than a reliance on custom and tradition. Today in modern thought good is determined by reasoning from scientifically established facts, and we are prone to put a limit on man's individual freedom, a limit imposed by social responsibility.

Milton's place is with the proponents of individual freedom. His consciousness of the necessity of breaking ties with the past to advance thought is shown in his exhortation to Parliament: "Custom countenances orror - . The greatest burden in the world is superstition...nl He believed that man should not submit

1. MIIton, op c1t., pp. 573, 575. supre, p. 55 . 
to custom but should plan his own desting. The bondage of tradition was to be overcome by the Reformation principle of gaining enlightenment directly from the scriptures.

The fact that Milton lived when he did, during the latter part of the Reformation during puritan supremacy in England, had great bearing on his divorce writinga. He was forced to use the sanctions of his time to support his arguments. Since the scripture was then the basis of all reasoning, he could not and did not go reasonably far beyond it in search of authority. His growing away from Greek classical thought toward the Puritan form of Hebraic culture had a narrowing influence on his work. Even Nature and Reason were referred to the Bible and could not be used as arguments in themselves. In view of this situation the divorce debate in which Milton participated degenerated into pamphleteering. After the Doctrine and Discipline of Divorce, in which his cause for divorce was stated, the ensuing pamphlets, the Judgment of Martin Bucer and Tetrachordon were only justifications for his interpretations of the scripture and exceedingly detailed studies of Biblical references to divorce. Colasterion sank to the low level of name calling, personalities, and coarse 
language which in those times was a customary form of argument. Another age or background might have influenced Milton to have produced his ideas in forms of thinking and writing that would have been of lasting interest.

Another Iimitation imposed by Puritan thought was the idea of the superiority of man to woman. The fact that Milton's arguments and provisions for divorco were almost entirely from the theory of the superiority of man is a decided weakness in the light of modern thought. H1s low opinion of women is not consistent with the modern viewpoint and would not receive much support from present day sociologists.

Milton, however, was more advanced than his contemporaries in that at his best he put the discussion on a higher level through an interpretation of man's nature and on the grounds of psychology. He realized that the nature of man is such that a dissatisfied or frustrated mind, caused by repression or hatred, blocks the full development of the individual. Then tendencies toward degeneracy such as fanaticism, defeatism, or extreme passion occur which keep him from developing into a good citizen or a good Christian. This recognition of cause and effect in the behavior of individuals 
was a stop far in advance of Milton's time, and places his thought on divorce in line with present sociological trends. In this respect he illustrates the famous belief of shelley that poets are the unacknowledged legislators of mankind. 
BIBLIOGRAPHY 


\section{BIBLIOGRAPHY}

\section{A. Boors}

Barnett, James Herwood, Divorce and the American Dirorce Hovel. Philadelphia: University of Pennsylvania Pros8, 1939. $168 \mathrm{pp}$.

Cahen, Alfred, Statistical Analysis of American Divoroe. New York: Columbia University Press, 1932. 169 pp.

Hanford, James Ho11y, A Milton Handbook. New York: F. S. Crofts and company, 1926. 304 pp.

Hanford, James Holly, A Miton Handbook. Third edition; Now York: F. S. Crotta and Company, 1939. 439 pp.

Haller, V1111em, The Rise of Paritanism. New York: Columbia University Press, 1938. $464 \mathrm{pp}$.

Iarson, Martin A., The Modernity of Milton. Chicago: University of Chicago Press, 1927. 277 pp.

Marriage and Diroree 1932. U. S. Department of Commerce. Washington: Burealu of the Census, 1934. $29 \mathrm{pp}$.

Masson, David, Ilfe of John Milton, Vol. III. Iondon: Macmilian company, 1813. 129 pp.

Pattison, Mark, Milton. John Morley, oditor, Bnglish Men of Letters Series. New York and London: Herper and Brothers, 1901. 215 pp.

Powe11, Chilton I., English Domestic Relations 1487-1653. New York: Columbia University Press, 19I7. 274 pp.

Raleigh, Walter A., Malton. New York and Iondon: G. P. Putnam's Sons, 1900. $286 \mathrm{pp}$.

Saurat, Denis, Milton: Man and Thinker. Now York: The Dial Press, $1925.363 \mathrm{pp}$.

Westermarck, E. A., Future of Marriage in Western Civilization. New York: Hacmilian Company, 1936. 281 pp.

Westermarck, E. A., History of Human Marriege. Iondon: Macmilian and Company, 1921. 3 v018. 
Milton, John, The Student's Milton. Frank Patterson, editor. New York: H. S. Crofts and Company, 1931. $1090 \mathrm{pp}$.

\section{B. PERIODICAI ARTICLES}

"Divorce too Easy for Iutherans," Iiterary D1gest, CVII (November 8, 1930), 21 .

Hanford, James Holly, "The Chronology of Milton's Private Studies," PMLA, XXXIV (1921), 251-314.

Holzberg, Julius, "Divorce in Russia and America," Nation, CXXVIII (1929), 734-747. Social Solence Abstracts, I (1929), 1530 .

Iwasak1, Yasa, "Divorce in Japan," American Journal of Soclology, XXXVI $(1930), 435-446$. Soc1aI Science Abstracts, III (1931), 448.

Larson, Martin A., "The Influence of Milton's Divorce Mracts on Farquhar's Beaux' Stratagem," PMTA, ZXXIX (1924), 174-178.

"Iimiting Divorce for Fresbyterians," Iiterary Digest, XCV (December 10, 1927), 28, 29.

Martin, Burns, "The Date of Milton's First Marriage," Studies in Philology, XXV (1928), 457-462.

Pasche-0serki, N., "Marriage and Divorce in Soviet Ruseia," Noue Generation, VIII-IX (1929), 225-23I. Social Science Abstracts, II (1930), 720.

Tillotson, H. S., "Scandinavia's Solution of the Dirorce Problem," Current History, XXXIV (1931), 551-554. Social Science Abstracts, III (1931), 1777.

C. ENCYCLOPAEDIA ARTICLES

Foleg, W. M., "Marriage (Christian)," Encyolopaodia of Religion and Ethics, VIII, 433-443. James Hastings, editor. New York: Charles Scribners' and Sons, 1925 . 
Hankins, Frank, "Divoroe," Encyclopaedia of the Social Sciences, V, i77-I84. Now York: Macmillan Company, 193\%.

Kennedy, D. J., "Sacraments," The Catholic Encyclopedia, XIII, 295-305. New York: The kncyclopedia Press, 1909.

Lehnkuhl, August, "Marriage," The Catholic Encyclopedia, IX, 691-715. New York: The Encyclopedia Pre88, 1909.

Porphyrios, Archbishop, "The Eastern Church," Encyclopeedia of Religion and Ethice, V, 134-136. James Hastings, editor, New York: Charles Scribners' and Sons, 1925 .

Smith, Walter George, "Divorce," The Catholic Encyclopedia,

v, 54-69. Now York: The Encyclopedia Press, 1909. 